\title{
A site-level comparison of lysimeter and eddy covariance flux measurements of evapotranspiration
}

\author{
Martin Hirschi $^{1}$, Dominik Michel ${ }^{1}$, Irene Lehner ${ }^{1, a}$, and Sonia I. Seneviratne ${ }^{1}$ \\ ${ }^{1}$ Institute for Atmospheric and Climate Science, ETH Zurich, Universitätstrasse 16, 8092 Zurich, Switzerland \\ ${ }^{a}$ present address: Centre for Environmental and Climate Research (CEC), University of Lund, Lund, Sweden \\ Correspondence to: Martin Hirschi (martin.hirschi@env.ethz.ch) and Sonia I. Seneviratne (sonia.seneviratne@env.ethz.ch)
}

Received: 20 May 2016 - Discussion started: 15 June 2016

Revised: 16 December 2016 - Accepted: 5 February 2017 - Published: 28 March 2017

\begin{abstract}
Accurate measurements of evapotranspiration are required for many meteorological, climatological, ecological, and hydrological research applications and developments. Here we examine and compare two wellestablished methods to determine evapotranspiration at the site level: lysimeter-based measurements $\left(E_{\mathrm{L}}\right)$ and eddy covariance $(\mathrm{EC})$ flux measurements $\left(E_{\mathrm{EC}}\right)$. The analyses are based on parallel measurements carried out with these two methods at the research catchment Rietholzbach in northeastern Switzerland, and cover the time period of June 2009 to December 2015. The measurements are compared on various timescales, and with respect to a 40-year lysimeter-based evapotranspiration time series. Overall, the lysimeter and EC measurements agree well, especially on the annual timescale. On that timescale, the long-term lysimeter measurements also correspond well with catchment water-balance estimates of evapotranspiration. This highlights the representativeness of the site-level lysimeter and EC measurements for the entire catchment despite their comparatively small source areas and the heterogeneous land use and topography within the catchment. Furthermore, we identify that lack of reliable EC measurements using open-path gas analyzers during and following precipitation events (due to limitations of the measurement technique under these conditions) significantly contributes to an underestimation of $E_{\mathrm{EC}}$ and to the overall energy balance gap at the site.
\end{abstract}

\section{Introduction}

Evaporation $E$ from land, also termed evapotranspiration, is an essential contributor to the water and energy balances on continents. It returns about $60 \%$ of the precipitated water on land back to the atmosphere and also uses up more than $50 \%$ of all net radiation available on land (e.g., Oki and Kanae, 2006; Trenberth et al., 2009; Jung et al., 2010; Seneviratne et al., 2010; Wang and Dickinson, 2012). In addition, it is coupled to the carbon dioxide $\left(\mathrm{CO}_{2}\right)$ uptake by vegetation (e.g., Farquhar and Sharkey, 1982; Sellers et al., 1996; Ciais et al., 2005; Reichstein et al., 2013), which implies important links between carbon and water cycles. Furthermore, evapotranspiration is related to other nutrient cycles such as the nitrogen cycle (Larcher, 2003).

Approaches to measure or estimate evapotranspiration are diverse and can include ground observations, remote sensingbased estimates, diagnostic techniques, as well as modeling and reanalyses (e.g., Seneviratne et al., 2010; Jiménez et al., 2011; Mueller et al., 2011; Wang and Dickinson, 2012). Despite their relative scarcity, the best-established reference measurement remains ground observations, which can be for example either performed with the lysimeter technique commonly used in hydrology (e.g., Maidment, 1992; Rana and Katerji, 2000; Seneviratne et al., 2012), or the eddy covariance (EC) flux measurement technique established in micrometeorology (e.g., Baldocchi et al., 2001; Aubinet et al., 2012). Both techniques hold specific intrinsic limitations (see Sect. 2).

Unfortunately, long-term parallel measurements of evapotranspiration with different techniques are rare. Many studies are limited in terms of number of methods and/or length of analyzed time period (e.g., Schume et al., 2005; Kosugi and Katsuyama, 2007; Castellví and Snyder, 2010; Wang and Dickinson, 2012, and references therein). Reported differences between lysimeter and EC measurements from these 
short-term comparisons amount from a few percent up to $30 \%$, with EC evapotranspiration being mostly lower than the lysimeter-based values (e.g., Chávez et al., 2009; Ding et al., 2010; Gebler et al., 2015). It is also worth mentioning the BEAREX08 field experiment, within which several methods of determining evapotranspiration were evaluated at different spatial scales for one vegetation period (Evett et al., 2012a, b) and substantial differences between EC and lysimetry were reported (Alfieri et al., 2012). In particular, the impact of surface heterogeneity (i.e., vegetation density) on the uncertainties of both lysimeter and EC measurements, as well as the influence of advective fluxes and energy balance closure deficits on the discrepancy between the two methods were investigated. Over $35 \%$ of the discrepancy could be attributed to differences in vegetation, while for the rest imperfect energy balance closure, advective effects and sensor-related measurement uncertainties were responsible.

The purpose of the present study is to compare lysimeterand EC-based measurements of evapotranspiration in the pre-alpine Rietholzbach catchment, which is characterized by a unique hydroclimatological record, including lysimeter measurements since 1976 (Seneviratne et al., 2012). As compared to numerous previous studies (see above), which were carried out in irrigated agroecosystems in semi-arid or arid climate, the presented inter-comparison is based on data of a non-irrigated environment in a temperate humid climate. In 2009, EC sensors were installed, thus allowing for an extensive, multi-year comparison between the two techniques (as compared to the shorter-term comparisons of previous studies). Furthermore, we use the catchmentwide water balance as an additional constraint for estimated evapotranspiration on the yearly timescale. Hence, we compare three approaches to measure or estimate evapotranspiration, which vary both in temporal resolution (from minutes to a year) and spatial scale (from $\mathrm{m}^{2}$ to $\mathrm{km}^{2}$ ). This allows us to evaluate (i) the correspondences between the two well-established local-scale evapotranspiration measurement techniques, (ii) the representativeness of these local-scale measurements for the catchment, and (iii) the quality of the EC measurements under the considered conditions at the site.

This article is structured as follows: the methods and data employed in this study are presented in Sect. 2. Section 3 shows the resulting evapotranspiration estimates by the different techniques and on different timescales. Section 4 discusses the results, and the summary and conclusions of this study are provided in Sect. 5 .

\section{Methods and data}

\subsection{Site description and catchment characteristics}

The measurements considered in this study were conducted at the hydrometeorological research catchment Rietholzbach in northeastern Switzerland $\left(47.38^{\circ} \mathrm{N}, 8.99^{\circ} \mathrm{E}\right.$; $795 \mathrm{~m}$ a.s.l.; see Seneviratne et al., 2012 for an overview of the site). The hilly, pre-alpine catchment (elevation range: 682$950 \mathrm{~m}$ a.s.1.) drains an area of $3.31 \mathrm{~km}^{2}$ and is a headwater catchment of the Thur river. The region is characterized by a temperate humid climate with a mean air temperature $T_{\text {air }}$ of $7.1^{\circ} \mathrm{C}$ and ample precipitation $P$ with a mean annual sum of $1438 \mathrm{~mm} \mathrm{yr}^{-1}$ (data basis 1976-2015, Fig. 1a and b). Net radiation $R_{\mathrm{n}}$ exhibits a clear seasonal pattern with on average $105 \mathrm{~W} \mathrm{~m}^{-2}$ in summer and $-7 \mathrm{~W} \mathrm{~m}^{-2}$ in winter (data basis 2000-2015, Fig. 1c). Predominantly weak winds (77\% below $2 \mathrm{~m} \mathrm{~s}^{-1}$ ) blow along the east-west orientation of the valley (Fig. 2). Catchment runoff $Q_{\mathrm{C}}$ is strongly related to subsurface storage (Teuling et al., 2010a) and shows an annual mean of $104 \mathrm{~L} \mathrm{~s}^{-1}$, which corresponds to $991 \mathrm{~mm} \mathrm{yr}^{-1}$. It displays the lowest values in summer and its peak value during snowmelt in March (data basis 1976-2015, Fig. 1d). The conglomerate Nagelfluh, the main parent rock type, originates from the Würm glaciation. The soil type and depth exhibit a high spatial variability. Overall, shallow Regosols dominate on steep slopes, deeper Cambisols are found in flatter areas, and gley soils are located in the vicinity of small creeks. Land use has undergone no major changes since the start of the measurements in late 1975 and is highly related to the topography. On slopes and along creeks, in about onefourth of the area, forest dominates. Otherwise the area is used as grassland and partially as pasture. The catchment is only sparsely populated.

Most measurements considered in this article are conducted at the site "Büel", which is located in a grassland area next to the valley bottom in the upper part of the $\mathrm{Ri}$ etholzbach catchment (see Fig. 2 and https://s.geo.admin.ch/ 6de2dcf3b5). The ongoing measurements include standard meteorological and hydrological variables such as air temperature, precipitation, air humidity, radiation, soil moisture, runoff, and groundwater level. Evapotranspiration measurements are provided by a lysimeter and an eddy flux tower (see Fig. 2 for an overview on the setup of these measurements). Further details on the relevant instrumentation for this study are given in the following sections. Seneviratne et al. (2012) provided an overview of the characteristics of the catchment and of measurements at the site. For more general information about the catchment we also refer to http://www.iac.ethz.ch/url/rietholzbach.

\subsection{Lysimeter measurements}

Lysimetry is a well-established technique to measure evapotranspiration (e.g., Maidment, 1992; Rana and Katerji, 2000; Goss and Ehlers, 2009; Meissner et al., 2010; see also Seneviratne et al., 2012, for a recent overview). Lysimeters are vessels containing a soil column in near-natural condition. Weighing lysimeters allow for the quantitative measurement of water changes within the soil column and thus, in combination with precipitation and lysimeter seepage measurements, also the estimation of evapotranspiration. 

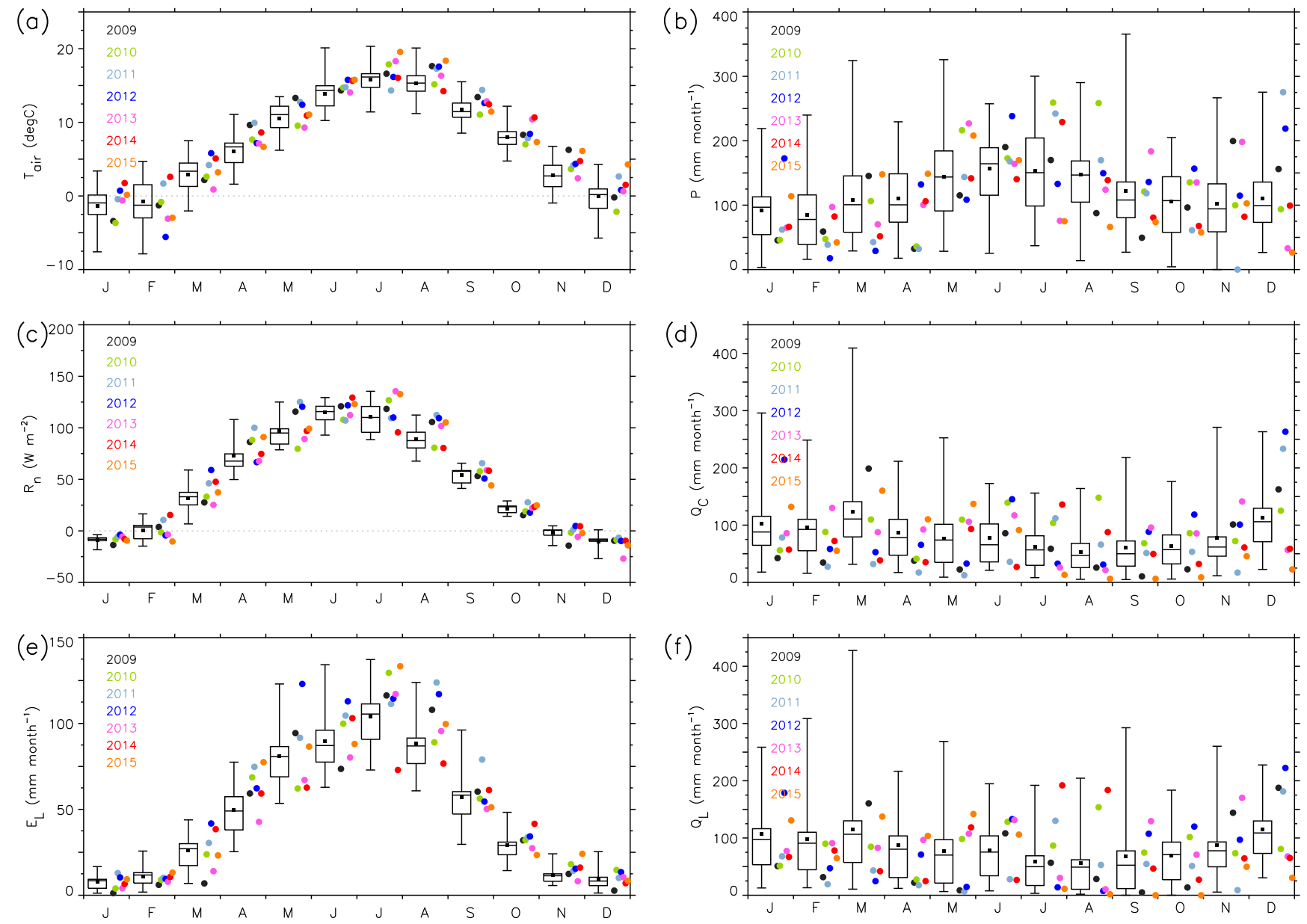

Figure 1. Box plots showing the median, interquartile range as well as minimum and maximum of monthly climatological values (in black, climatological mean included as black square) with the monthly values for the period of investigation 2009-2015 (in color) for (a) air temperature $T_{\text {air }}$, (b) precipitation $P$, (c) net radiation $R_{\mathrm{n}},(\mathbf{d})$ catchment runoff $Q_{\mathrm{C}},(\mathbf{e})$ lysimeter evapotranspiration $E_{\mathrm{L}}$, and (f) lysimeter seepage $Q_{\mathrm{L}}$.
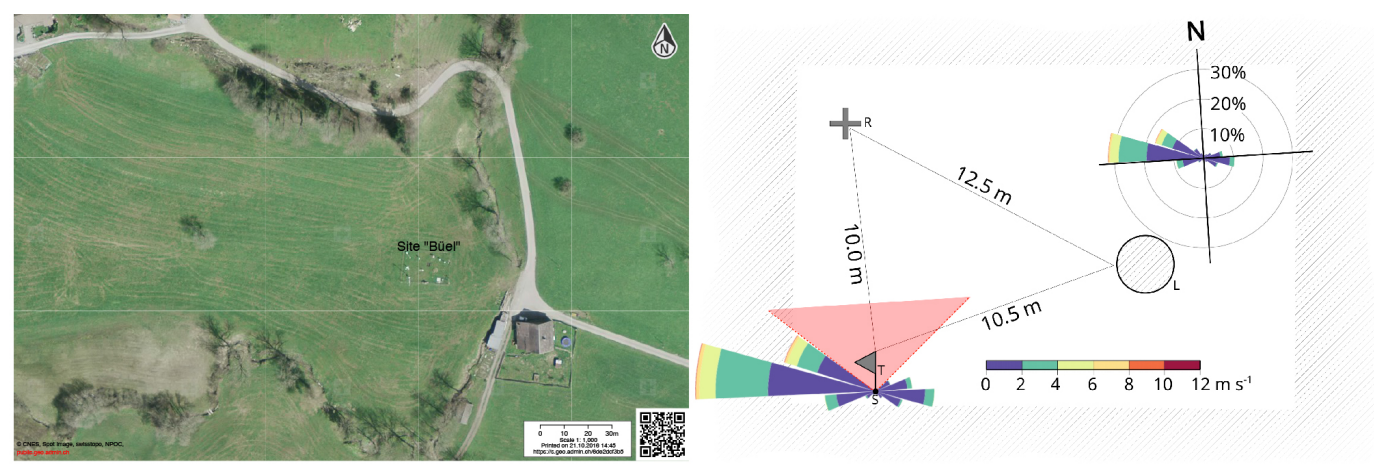

Figure 2. Left panel: aerial map of the site (see https://s.geo.admin.ch/6de2dcf3b5 for an interactive online version of the map) and right panel: schematics of the EC tower (denoted T), lysimeter (L), and radiation (R) measurement setup as well as the frequency of wind direction and velocity at the site "Büel" (white rectangle defines the area of the measurement field). The distance between the tower and the sonic (S) volume equals $1.17 \mathrm{~m}$. The wind sector obstructed by the tower and the IRGA is highlighted in red and masked for the analyses (from 310 to $\left.50^{\circ}\right)$. The identical hatching of the surrounding grassland and the lysimeter surface indicates that the latter is treated according to the former (see text for details). 
Formally, the lysimeter evapotranspiration $E_{\mathrm{L}}(\mathrm{mm})$ within a given time interval $\Delta t$ (here $1 \mathrm{~h}$ ) is estimated from the initial weight $W_{t}$ minus the final weight $W_{t+1}$ (both in $\mathrm{kg}$ ), the precipitation $P(\mathrm{~mm})$, and lysimeter seepage $Q_{\mathrm{L}}(\mathrm{mm})$ at the vessel bottom:

$E_{\mathrm{L}}=\frac{W_{t}-W_{t+1}}{\rho_{\mathrm{w}} \pi r^{2}}+P-Q_{\mathrm{L}}$,

where $\rho_{\mathrm{W}}$ stands for the density of water $\left(\mathrm{kg} \mathrm{m}^{-3}\right)$ and $r(\mathrm{~m})$ for the radius of the lysimeter. For the comparison with eddy covariance measurements, we derive a parallel time series " $E_{\mathrm{L}_{0}}$ " in which $E_{\mathrm{L}}$ is set to 0 during hours with precipitation ( $P \geq 0.1 \mathrm{~mm}, 15.4 \%$ of data), as no reliable data are available from the EC measurements in those cases (see Sect. 2.3).

The Rietholzbach lysimeter has a surface area of $3.1 \mathrm{~m}^{2}$ (radius of $1 \mathrm{~m}$ ) and a total depth of $2.5 \mathrm{~m}$ including a gravel filter layer at the bottom. This size of vessel ensures a higher quality of the measurements (see Seneviratne et al., 2012, and references therein). The lysimeter weight is measured with three load cells and a resolution of $100 \mathrm{~g}$, which corresponds to a water column of approximately $0.03 \mathrm{~mm}$. The surface is covered by grass of similar species composition and treated according to the surrounding grassland (same cutting scheme, but synthetic fertilization instead of slurry; see also Fig. 2). At its installation at the site "Büel" in late 1975, the lysimeter was backfilled with a typical gleyic Cambisol. Seepage at the lysimeter lower boundary is measured by a tipping bucket with a volume of $50 \mathrm{~mL}$, i.e., with a resolution of $0.02 \mathrm{~mm}$ (Gurtz et al., 2003). Following the recommendations of the World Meteorological Organization (WMO, 2008), precipitation data were not derived from the lysimeter measurements but were taken from a standard tipping bucket (see Sect. 2.5).

A key requirement for the accurate estimation of local evapotranspiration is the representativeness of the lysimeter for the surrounding area in terms of soil conditions, vegetation composition, and treatment. Major drawbacks are the existence of the vessel and its specific design (Allen et al., 2011; WMO, 2008). At the investigated site, this implies the main following limitations:

i. The lateral water transport is not contributing to the lysimeter water storage dynamics. This point is assessed as being relatively negligible, as the lysimeter is located in a flat area close to the valley bottom and surrounded by a slight and uniform slope. Thus, potential lateral inflow and outflow to the investigated soil volume are assumed to be equal.

ii. There is no connection to the groundwater. This may become potentially important under drought conditions (e.g., Rana and Katerji, 2000; Seneviratne et al., 2012) even for a grass-covered lysimeter in a temperate humid climate. iii. Drainage occurs by gravitation only as soil suction is not artificially reproduced within the vessel.

iv. Time periods with snow cover have to be analyzed with special care as snow drift induced by wind as well as snow bridges to the surrounding can falsify the weight measurement.

Despite these issues, Seneviratne et al. (2012) show that the Rietholzbach lysimeter seepage and catchment runoff display very similar monthly dynamics, which suggests to a first approximation, that the lysimeter is well representative for the entire catchment despite the scale discrepancy and mentioned limitations. The largest discrepancies between lysimeter seepage and catchment runoff are found in March, most likely linked to a higher spatial variability of hydrological processes in that month, due to snowmelt and the onset of the growing season.

Lysimeter data analyzed in this study cover the time period 1 June 2009 to 31 December 2015 (start being restricted by the availability of the EC measurements; see Sect. 2.3). In addition, we refer to the climatological lysimeter time series dating back to 1976 (see Sect. 2.5). Evapotranspiration is calculated in hourly time steps according to Eq. (1) and taking into account the weight changes due to management activities. Missing values in lysimeter weight change $W_{t}-W_{t+1}$ $(<0.1 \%$ of data) are filled by a linear interpolation as the gaps were short and no precipitation occurred. For lysimeter seepage $Q_{\mathrm{L}}$ missing values $(<0.1 \%$ of data) are filled manually preserving the actual seepage pattern. Evapotranspiration is defined here as an upward flux, i.e., comprising positive values only, as the lysimeter accuracy does not allow one to resolve dew formation. Yet, Eq. (1) can result in negative $E_{\mathrm{L}}$ values, because the measurements entering the calculation are based on instruments with differing resolutions, and because they can be biased due to sensor uncertainty. The latter is in particular the case for the precipitation measurements, which are often biased due to an undercatch (e.g., Sevruk, 1982; Adam and Lettenmaier, 2003). Days comprising negative $E_{\mathrm{L}}$ are thus treated as described in Jaun (2003) to eliminate such negative values, being consistent with the scheme used for the climatological data series dating back to 1976 (see Sect. 2.5). It takes into account the amount and predominant sign of $E_{\mathrm{L}}$ during such days. The method mainly affects the winter period, when it leads to a reduction of the overall amount of positive $E_{\mathrm{L}}$ as compared to, e.g., simply setting all negative $E_{\mathrm{L}}$ values to 0 (not shown), as the occurrence of negative $E_{\mathrm{L}}$ is increased during this season. Based on measured values, a threshold for maximum realistic $E_{\mathrm{L}}$ of $0.2 \mathrm{~mm} \mathrm{~h}^{-1}$ during nighttime (global radiation $R_{\mathrm{sd}}<10 \mathrm{~W} \mathrm{~m}^{-2}$ ) and periods with snow cover (albedo $\alpha>0.5$ ) is applied. In addition, a limitation of $E_{\mathrm{L}}$ is defined as a function of $R_{\mathrm{sd}}$. The subsequent gap filling is conducted in two steps: (i) missing nighttime values ( $0.7 \%$ of data) are set to 0 , and (ii) for missing daytime values $(0.8 \%$ of data) a 
linear regression with global radiation $R_{\mathrm{Sd}}\left(R^{2}: 0.67\right)$ is applied.

\subsection{Eddy covariance measurements}

The eddy covariance method estimates the vertical mass flux of water vapor $\left(E_{\mathrm{EC}}\right)$ exchanged by an ecosystem based on fast measurements of vertical wind velocity $w\left(\mathrm{~m} \mathrm{~s}^{-1}\right)$ and specific humidity $q\left(\mathrm{~kg} \mathrm{~m}^{-3}\right)$, respectively, on their turbulent fluctuations (denoted by a prime):

$E_{\mathrm{EC}}=\overline{w^{\prime} q^{\prime}}$.

$E_{\mathrm{EC}}$ has been measured at the Rietholzbach catchment since late May 2009. The measurements are conducted on a $9 \mathrm{~m}$ flux tower, installed at the site "Büel" (see Fig. 2 and https: //s.geo.admin.ch/6de2dcf3b5) and equipped on three levels with an ultrasonic anemometer thermometer (sensor type CSAT3, Campbell Scientific Inc., USA; hereafter referred to as "sonic"). On the bottom and top levels, an open-path $\mathrm{CO}_{2} / \mathrm{H}_{2} \mathrm{O}$ infrared gas analyzer (sensor type Li-7500, LICOR Biosciences, USA; hereafter referred to as "IRGA") complete the setup. The instruments are operated at $10 \mathrm{~Hz}$ and data are saved with a CR3000 data logger (Campbell Scientific Inc., USA). The present study is based on data obtained from the sensors at the lowest level $(2 \mathrm{~m}$ above ground), as their source area is smallest and closer to the lysimeter (see Fig. 2), and therefore, they experience more homogeneous physical environmental conditions. However, up to $10 \%$ of the measurements are potentially affected by obstacles (trees and a farmhouse) in the area, whereas only $1 \%$ of the measurements within the main wind direction (i.e., from west, see Fig. 2) are potentially influenced (Peter, 2011, based on the footprint model of Kljun et al., 2004). Note that this level is well above the vegetation height (mostly below $15 \mathrm{~cm}$, maximum $40 \mathrm{~cm}$ ), and clear of the roughness sublayer (estimated three times the canopy height; see Kaimal and Finnigan, 1994; Foken, 2008). In this study we consider data from the time period 1 June 2009 until 31 December 2015.

To enable the comparison with the lysimeter estimates, the statistics were calculated on an hourly time step following the methodology described in, e.g., Lee et al. (2004) or Aubinet et al. (2012). This includes a time lag correction of $w$ and $q$ by maximization of their covariance, the application of the planar fit method after Wilczak et al. (2001) for the coordinate rotation, spectral correction (Moore, 1986), conversion of the buoyancy flux into the sensible heat flux (Schotanus et al., 1983), and correction of density fluctuations (Webb et al., 1980). As open-path IRGAs are not reliably measuring when water is accruing on the optical elements, $\lambda E_{\mathrm{EC}}$ is explicitly set to 0 during hours with precipitation $(P \geq 0.1 \mathrm{~mm}, 15.4 \%$ of the data).

Figure 2 displays the location of the tower with respect to the lysimeter and the radiation measurements, together with the frequency of wind direction and velocity at the location. The horizontal separation distance between sonic volume and IRGA volume amounts to $0.2 \mathrm{~m}$ both laterally and longitudinally, with the IRGA being situated west of the sonic (not shown). EC data are masked when the tower and the IRGA are in the upwind direction of the sonic volume (i.e., from 310 to $50^{\circ}$, red sector) in order to avoid impacts on the measured turbulent fluxes. This is the case for $10.6 \%$ of the data.

Evapotranspiration $E_{\mathrm{EC}}$ is related to the surface energy balance as follows:

$R_{\mathrm{n}}-G=H+\lambda E_{\mathrm{EC}}$,

where $R_{\mathrm{n}}$ refers to the net radiation, $G$ is the surface soil heat flux (see below), $H$ stands for the sensible heat flux, and $\lambda E_{\mathrm{EC}}$ stands for the latent heat flux, where $\lambda\left(\mathrm{J} \mathrm{kg}^{-1}\right)$ is the latent heat of vaporization. Details on the measurements of $R_{\mathrm{n}}$ and $G$ are given in Sect. 2.5. The storage of energy between the surface and the measurement height is neglected in the analyzed measurements as these are performed at $2 \mathrm{~m}$ above short grassland (vegetation height mostly below $15 \mathrm{~cm}$, maximum $40 \mathrm{~cm}$ ). However, it is not negligible for tall vegetation (e.g., Foken et al., 2006). In addition, effects of diurnal storage changes can be averaged out when considering daily instead of hourly energy balances (e.g., Leuning et al., 2012; Anderson and Wang, 2014).

Advective fluxes are also not considered in Eq. (3). This effect can contribute to a non-closure of the surface energy balance (e.g., Leuning et al., 2012, see also below). The vertical component of advection of latent and sensible heat (see e.g., Paw U et al., 2000; Casso-Torralba et al., 2008) can be assessed at the site following the notation of Lee (1998), which is based on the average vertical gradient of moisture or temperature multiplied by the mean vertical wind speed at a specific level. For a quantitative estimate of the horizontal component of advection, measurements are not available at the site and its surroundings. Possible reasons for horizontal advection include slope drainage in complex terrain and heterogeneous land cover (e.g., Katul et al., 2006). Concerning the first reason (slope drainage), the wind from the southfacing valley slope is masked in all analyses as it includes the tower (see above). Concerning the impact of surface heterogeneity, we estimate the potential effect on the energy balance closure by separating the analyses into three wind sectors (i.e., east, west, and south wind directions). While the west sector (i.e., the main wind direction) features homogeneous land cover and horizontal advection should thus not be relevant, the east sector is potentially impacted by a small street and a farmhouse (see Fig. 2).

For the latent heat flux $\lambda E_{\mathrm{EC}}$ the same data constraints are applied as for lysimeter evapotranspiration $E_{\mathrm{L}}$, i.e., during nighttime conditions, periods with snow cover, and limitation by $R_{\mathrm{sd}}$ (see Sect. 2.2). Under the present generally humid climate conditions at Rietholzbach, net radiation $R_{\mathrm{n}}$ is the main driver and limiting factor for $\lambda E_{\mathrm{EC}}$ (Teuling et al., 2010b; Seneviratne et al., 2012). Thus, gaps in the $\lambda E_{\mathrm{EC}}$ time series (31.1\% of data) are filled by a linear regression $\left(R^{2}: 0.90\right)$ of 
these two variables. However, it should be noted that the simple regression with radiation could lead to errors when evapotranspiration is constrained by soil moisture (e.g., Seneviratne et al., 2010). Overall, the relation between the $\lambda E_{\mathrm{EC}}$ and the lysimeter time series is not changed by the gap filling (not shown).

As commonly observed with using EC data (e.g., Twine et al., 2000; Wilson et al., 2002; Franssen et al., 2010), the energy balance is not closed at the investigated site (see Sect. 3.2), i.e., the available energy $\left(R_{\mathrm{n}}-G\right)$ is generally higher than the sum of the turbulent fluxes $\left(H+\lambda E_{\mathrm{EC}}\right)$. This known issue of the EC method is extensively discussed in the literature (e.g., Mahrt, 1998; Foken, 2008; Aubinet et al., 2012; Leuning et al., 2012). It is important to address this issue also in light of the use of EC data for model validation (e.g., Jaeger et al., 2009).

Several approaches can be used to force close the energy balance. Here we apply three different simple approaches to enforce the energy balance closure on an hourly basis, assigning the gap to

i. both $H$ and $E_{\mathrm{EC}}$ according to the Bowen ratio $\beta\left(E_{\mathrm{EC} \_ \text {BOWEN }}\right)$

ii. sensible heat-flux only $\left(E_{\mathrm{EC} \_\mathrm{H}}\right)$

iii. latent heat-flux only $\left(E_{\mathrm{EC} \_\mathrm{E}}\right)$.

Due to weak turbulent conditions, small turbulent fluxes, and a poor definition of the Bowen ratio during nighttime, the approaches are only applied to daytime values $\left(R_{\mathrm{sd}} \geq 10 \mathrm{~W} \mathrm{~m}^{-2}\right)$. Approach (i) ( $\left.E_{\mathrm{EC} \_ \text {BOWEN }}\right)$ is a commonly used assumption in the literature (e.g., Twine et al., 2000; Jaeger et al., 2009; Jung et al., 2010). It assumes that the Bowen ratio is correctly measured by the EC method so that $\lambda E_{\mathrm{EC}}$ and $H$ can be adjusted to balance Eq. (3). Approaches (ii) and (iii) represent two extreme assumptions but they are useful as they indicate the entire range of possible energy balance options (given that $R_{\mathrm{n}}$ and $G$ are correctly estimated and no other fluxes (e.g., advection) or storage terms are of importance; see also Sect. 4.2). For comparison, approach (i) is also applied on daily timescale (i.e., based on daily aggregated fluxes).

\subsection{Catchment water-balance measurements}

The catchment water balance integrates its components over the entire catchment area over longer time periods. While we focus here on the comparison of the lysimeter and EC evapotranspiration measurements, such catchment water-balance estimates provide an additional reference to evaluate the local-scale techniques. Using this approach, the evapotranspiration $E_{\mathrm{C}}$ is estimated as the difference between precipitation $P$ and catchment runoff $Q_{\mathrm{C}}$ (all in millimeters):

$E_{\mathrm{C}}=P-Q_{\mathrm{C}}$.
This approach implies that the change in catchment storage over the given time interval is 0 . This assumption generally only holds for long-term averages ( $\geq 1$ year). Although yearto-year variations in storage cannot be fully excluded (e.g., Seneviratne et al., 2012), it can be assumed to yield a reasonable estimate for hydrological years (October to September in Switzerland). In addition, catchment precipitation is estimated here using one precipitation gauge only (thus assumed to be spatially representative). This approach also assumes that all water is leaving the catchment through the discharge gauge at the catchment outlet (see below). Previous analyses suggest that both conditions are reasonably met for the study catchment (Gurtz et al., 2003; Seneviratne et al., 2012).

Precipitation data are taken from the standard tipping bucket (for details see Section 2.5). As the catchment evapotranspiration $E_{\mathrm{C}}$ is known to suffer from unrealistic negative values during winter (Lehner et al., 2010), related to high precipitation undercatch during snowfall (up to $60 \%$, see Gurtz et al., 2003), the precipitation data entering Eq. (4) is corrected for undercatch (based on Gurtz et al. 2003, Table 1 therein). Catchment runoff $\left(Q_{\mathrm{C}}\right)$ is captured at the catchment outlet at the gauge "Rietholz-Mosnang". This gauge is operated by the FOEN (Federal Office for the Environment, Hydrology Division, Berne, Switzerland). More information on the gauge is available on http://www.hydrodaten.admin. ch/en/2414.html (last access: 21 February 2017).

\subsection{Additional measurements at the site "Büel"}

Precipitation is measured by a standard tipping bucket installed at $1.5 \mathrm{~m}$. Data from parallel measurements with a standard tipping bucket at $0 \mathrm{~m}$ and a weighing pluviometer at $1.5 \mathrm{~m}$ at the same measurement site are used for quality assessment and gap filling. For remaining gaps, a regression with data from nearby meteorological stations operated by MeteoSwiss is applied.

Net radiation is derived from separate measurements of all four components of the radiation balance (CM21 and CG4, Kipp \& Zonen, NL, all ventilated) at a height of $2 \mathrm{~m}$ (see Fig. 2).

Soil heat flux is captured with three heat-flux plates (HFP01, Hukseflux, NL) installed at $0.05 \mathrm{~m}$ below ground and situated within a $1 \mathrm{~m}$ periphery, which are averaged for the analysis. Surface soil heat flux $G$ is determined following Fuchs and Tanner (1968) by calculating the change in heat storage above the sensors. This estimation is performed using the average of three soil temperature sensors (107T, Campbell Scientific Inc., USA) installed at the same locations as the heat-flux plates, as well as soil moisture (TRIMEIT, IMKO GmbH, D) and soil density measurements (Mittelbach et al., 2012). The ensemble of the three different locations for soil heat flux and soil temperature is used to account for the spatial heterogeneity of the soil matrix and thus to obtain surface soil heat-flux data, which are spatially represen- 
Table 1. Statistical properties of the catchment water balance for the hydrological years (i.e., October-September) 1976/1977 to 2014/2015 and the absolute values for the hydrological years $2009 / 2010$ to 2014/2015. $P$ denotes precipitation, $Q_{\mathrm{C}}$ catchment runoff, $Q_{\mathrm{L}}$ lysimeter seepage, $E_{\mathrm{C}}$ catchment evapotranspiration, and $E_{\mathrm{L}}$ lysimeter evapotranspiration. Units in $\mathrm{mm} \mathrm{yr}^{-1}$ (except for $E_{\mathrm{C}} / P$ and $E_{\mathrm{L}} / P$, which are dimensionless).

\begin{tabular}{lrrrrrrrrrrrr}
\hline & Mean & Median & Minimum & Maximum & SD & $\begin{array}{r}1976-2007 \\
\text { limatology }^{\mathrm{a}}\end{array}$ & $\begin{array}{r}2009 / \\
2010\end{array}$ & $\begin{array}{r}2010 / \\
2011\end{array}$ & $\begin{array}{r}2011 / \\
2012\end{array}$ & $\begin{array}{r}2012 / \\
2013\end{array}$ & $\begin{array}{r}2013 / \\
2014\end{array}$ & $\begin{array}{r}2014 / \\
2015\end{array}$ \\
\hline$P^{\mathrm{b}}$ & 1598 & 1591 & 1281 & 1967 & 193 & 1459 & 1830 & 1442 & 1594 & 1771 & 1498 & 1440 \\
& $(1446)$ & $(1443)$ & $(1177)$ & $(1764)$ & $(168)$ & & $(1715)$ & $(1346)$ & $(1453)$ & $(1597)$ & $(1403)$ & $(1294)$ \\
$Q_{\mathrm{C}}$ & 1006 & 967 & 716 & 1471 & 185 & 1063 & 1151 & 716 & 1025 & 1245 & 881 & 864 \\
$E_{\mathrm{C}}$ & 592 & 584 & 364 & 887 & 101 & 396 & 679 & 725 & 569 & 526 & 617 & 576 \\
$E_{\mathrm{C}} / P$ & 0.37 & 0.37 & 0.23 & 0.50 & 0.06 & 0.27 & 0.37 & 0.50 & 0.36 & 0.30 & 0.41 & 0.40 \\
$Q_{\mathrm{L}}$ & 1026 & 984 & 675 & 1506 & 187 & - & 1140 & 675 & 839 & 1196 & 1088 & 854 \\
$E_{\mathrm{L}}$ & 564 & 566 & 433 & 704 & 55 & 560 & 589 & 704 & 704 & 542 & 537 & 647 \\
$E_{\mathrm{L}} / P^{\mathrm{b}}$ & 0.36 & 0.36 & 0.26 & 0.49 & 0.06 & 0.38 & 0.32 & 0.49 & 0.44 & 0.31 & 0.36 & 0.45 \\
& $(0.40)$ & $(0.39)$ & $(0.28)$ & $(0.52)$ & $(0.06)$ & & $(0.34)$ & $(0.52)$ & $(0.48)$ & $(0.34)$ & $(0.38)$ & $(0.50)$ \\
\hline
\end{tabular}

${ }^{\mathrm{a}}$ from Seneviratne et al. (2012), based on calendar-year (January-December) values. ${ }^{\mathrm{b}}$ For $P$ (and $E_{\mathrm{L}} / P$ ) the statistics based on undercatch-corrected and uncorrected (in brackets) $P$ are provided (see Sect. 2.4).

tative for the footprint domain of all other measured components of the energy balance.

Note that soil heat flux was not measured during a 4-month period from July to October 2014 due to a logger failure. This leads to some gaps in the following comparisons due to the fact that the energy gap corrections (i.e., $E_{\text {EC_BOWEN }}$ and $E_{\text {EC_E}}$, see Sect. 2.3) cannot be applied for this time period. Apart from this period, the soil heat flux and net radiation time series only hold few and short gaps $(<0.1 \%$ of data), which are filled by a linear interpolation.

All measurements mentioned in Sect. 2 are ongoing. The descriptions refer to the instrumentation for the data since (at least) June 2009. The climatological data series (since 1976) are generally based on varying sensors (types), but have been homogenized over time. More details on the climatological record and respective instrumentation since 1976 can be found in Seneviratne et al. (2012) and in a German-language report (Gurtz et al., 2006).

\section{Results}

\subsection{Climate conditions in 2009-2015 compared with long-term climatology}

We first assess how the measurements in the study period compare with the long-term climatology to evaluate if the study period from 1 June 2009 to 31 December 2015 is representative for the mean climatological conditions at the site. Figure 1 displays the average monthly meteorological conditions during the study period compared to the longterm climatology with respect to air temperature $T_{\text {air }}$, precipitation $P$, net radiation $R_{\mathrm{n}}$, catchment runoff $Q_{\mathrm{C}}$, lysimeter evapotranspiration $E_{\mathrm{L}}$, and lysimeter seepage $Q_{\mathrm{L}}$. The long-term climatological values are derived over the time pe- riod 1976-2015, with the exception of net radiation, which has only been measured since 2000 at the site.

Temperature (Fig. 1a) during the study period ranges on average in the upper part of the distribution based on the climatological data series. This is consistent with the recorded long-term increasing temperature trend in Rietholzbach (Seneviratne et al., 2012) and in Switzerland (OcCC, 2008). The variability within the 7 years is similar to the climatology. Precipitation of the study period (Fig. 1b) shows high variability with extreme values in November 2011 (0 mm) and December $2011(275 \mathrm{~mm})$. Overall, the precipitation data shows that the spring season is often drier and the summer season often wetter in the 7 considered years compared to the long-term climatology. Absolute values and variability for $R_{\mathrm{n}}$ (Fig. 1c) are close to the long-term average. Catchment runoff and lysimeter seepage (Fig. 1d and f) show high variability within the 7 years and compared to the climatological values. $Q_{\mathrm{C}}$ and $Q_{\mathrm{L}}$ show a similar behavior (see also Seneviratne et al., 2012). Lysimeter evapotranspiration $E_{\mathrm{L}}$ often shows higher summer values (i.e., mostly for June and August) in 2009-2015 compared to the climatology.

Mean precipitation $P$ of a hydrological year sums up to $1598 \mathrm{~mm} \mathrm{yr}^{-1}$ (respectively $1446 \mathrm{~mm} \mathrm{yr}^{-1}$ when undercatch is not corrected), whereof about $37 \%$ are evaporated as $E_{\mathrm{C}}$ and about $63 \%$ leave the catchment as runoff $Q_{\mathrm{C}}$ (Table 1 ). All catchment water-balance components show a high yearto-year variability, which is highest for $Q_{\mathrm{C}}$ with respect to the mean. However, none of the components displays a significant trend over the entire time period (see also Seneviratne et al., 2012, for trends in calendar-year values over the time period 1976-2007). Figure 3 displays the catchment water balance for the hydrological years since 1976/1977. The comparison with the lysimeter-based evapotranspiration $E_{\mathrm{L}}$ suggests that in the long-term mean the $E / P$ ratio agrees well with the catchment water-balance approach. The discrepancies between $E_{\mathrm{C}}$ and $E_{\mathrm{L}}$ on a year-to-year basis are 


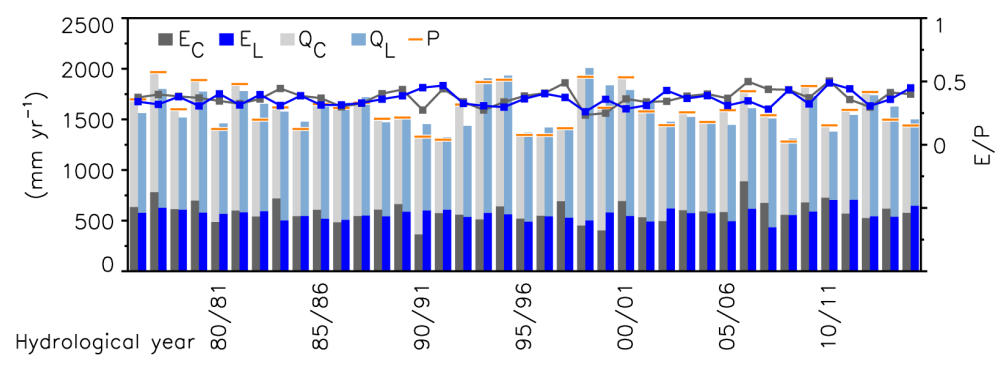

Figure 3. Catchment water balance for the hydrological years (i.e., October-September) 1976/1977 until 2014/2015. $E_{\mathrm{C}}$ denotes catchment evapotranspiration, $E_{\mathrm{L}}$ lysimeter evapotranspiration, $Q_{\mathrm{C}}$ catchment runoff, $Q_{\mathrm{L}}$ lysimeter seepage, and $P$ precipitation (corrected according to Gurtz et al. (2003), Table 1 therein). The lines show the ratio $E_{\mathrm{C}} / P$ (dark gray) respectively $E_{\mathrm{L}} / P$ (blue).

likely due to non-negligible year-to-year variations in terrestrial water storage (soil moisture, groundwater, snow). In fact, the non-equality of $\left(E_{\mathrm{L}}+Q_{\mathrm{L}}\right)$ vs. $P$ indicates annual storage variations at the lysimeter, while for $E_{\mathrm{C}}$ the change in catchment storage over the given time interval is assumed to be 0 (see Sect. 2.4).

The hydrological year 2009/2010 is one of the wettest hydrological years in terms of precipitation $(+14.5 \%$ resp. $+18.6 \%$ compared to the average, undercatchcorrected, and uncorrected values), yet the partitioning of $P$ into $Q_{\mathrm{C}}$ and evapotranspiration $\left(E_{\mathrm{C}}\right.$ and $\left.E_{\mathrm{L}}\right)$ is still close to the long-term average (Table 1). The pattern of the hydrological year 2010/2011, in contrast, is different. Precipitation is lower than average $(-9.8 \%$ resp. $-6.9 \%)$ for that year, but evapotranspiration $\left(E_{\mathrm{C}}\right.$ and $\left.E_{\mathrm{L}}\right)$ is up to 1.25 times the average, whereas runoff and seepage $\left(Q_{\mathrm{C}}\right.$ and $Q_{\mathrm{L}}$ ) display the lowest values of the entire period ( -28.8 and $-34.2 \%$ respectively compared to the average). It should be noted that the spring 2011 was very dry (e.g., Wolf et al., 2013; Wetter et al., 2014; Whan et al., 2015), which can partly explain these features. Both hydrological years 2009/2010 and 2010/2011 display amongst the highest evapotranspiration values since the beginning of the measurements $\left(E_{\mathrm{C}}\right.$ and $\left.E_{\mathrm{L}}\right)$. The year 2011/12 appears rather normal on the catchment scale, but the lysimeter again shows high $E_{\mathrm{L}}\left(+24.8 \%\right.$ compared to the average) and low $Q_{\mathrm{L}}$ $(-18.2 \%)$. This is followed by a wetter year $2012 / 2013$ with higher $P(+10.8 \%$ resp. $+10.4 \%), Q_{\mathrm{C}}(+23.8 \%)$ and $Q_{\mathrm{L}}(+16.6 \%)$, but lower $E_{\mathrm{C}}$ and $E_{\mathrm{L}}(-11.1 \%$ resp. $-3.9 \%$ ). The years $2013 / 2014$ and $2014 / 2015$ finally show again lower than average precipitation (up to $-10.5 \%$ ). For the catchment, this resulted in below normal $Q_{\mathrm{C}}$ for both years $(-12.4$ and $-14.1 \%)$ and close to normal $E_{\mathrm{C}}$ $(+4.2$ and $-2.7 \%)$. The lysimeter on the other hand shows for $2013 / 2014$ slightly enhanced $Q_{\mathrm{L}}(+6.0 \%)$ while $E_{\mathrm{L}}$ is close to normal $(-4.8 \%)$. For $2014 / 2015$ it experienced a pronounced drying with high $E_{\mathrm{L}}(+14.7 \%)$ and low $Q_{\mathrm{L}}$ $(-16.8 \%)$, related to the hot and dry summer of that year (e.g., Scherrer et al., 2016). Overall, the study period covers the climatological variability well, including both years with rather extreme conditions as well as years close to average conditions (see Table 1).

\subsection{Energy balance closure}

The energy balance closure as evaluated from the ordinary least-squares regression between the hourly estimates of the turbulent fluxes $\left(H+\lambda E_{\mathrm{EC}}\right)$ and the available energy $\left(R_{\mathrm{n}}-G\right)$ reaches values of 0.77 for the slope and $18.94 \mathrm{~W} \mathrm{~m}^{-2}$ for the intercept $\left(R^{2}: 0.94\right.$, Fig. $4 \mathrm{a}$; note ideal closure is represented by an intercept of 0 and slope of 1 ). The ratio of the total amount of the turbulent heat fluxes to available energy amounts to $101.9 \%$, indicating a surplus of turbulent energy. This is due to mostly slight positive nighttime values of the sum of the turbulent fluxes while available energy displays negative values during night (see Fig. $4 \mathrm{~b})$. Ignoring nighttime values $\left(R_{\mathrm{sd}}<10 \mathrm{~W} \mathrm{~m}^{-2}\right)$, the closure ratio amounts to $86.4 \%$; i.e., the sum of the turbulent fluxes $H+\lambda E_{\mathrm{EC}}$ is generally lower than the available energy $R_{\mathrm{n}}-G$. The regression between the daytime hourly estimates reveals a slope of 0.80 and intercept of $10.63 \mathrm{~W} \mathrm{~m}^{-2}$ $\left(R^{2}: 0.94\right)$. All these values are in the range of values reported in literature (e.g., Wilson et al., 2002). Note that the analyses presented here are based on measured data only (i.e., excluding gap-filled data) and masked for precipitation and for wind directions impacted by the tower (see also Sect. 4.2).

Hourly energy balance closure is also compared with daily closure for days where maximally five of the hourly values were gap-filled, which leaves 462 days of valid EC observations (Fig. S1 in the Supplement). The energy balance closure slightly improves on daily timescales: regression slopes increase from 0.76 to 0.84 , and $R^{2}$ from 0.95 to 0.97 . The increase of the energy balance closure from hourly to daily timescale hints at an effect of diurnal storage variations on hourly timescale, which tend to get averaged out on daily timescale (see Sect. 2.3).

As mentioned in Sect. 2.3, advective fluxes are not accounted for in the energy balance Eq. (3) and can contribute to the imbalance between the turbulent fluxes and the measured available energy. The estimated amount of vertical ad- 

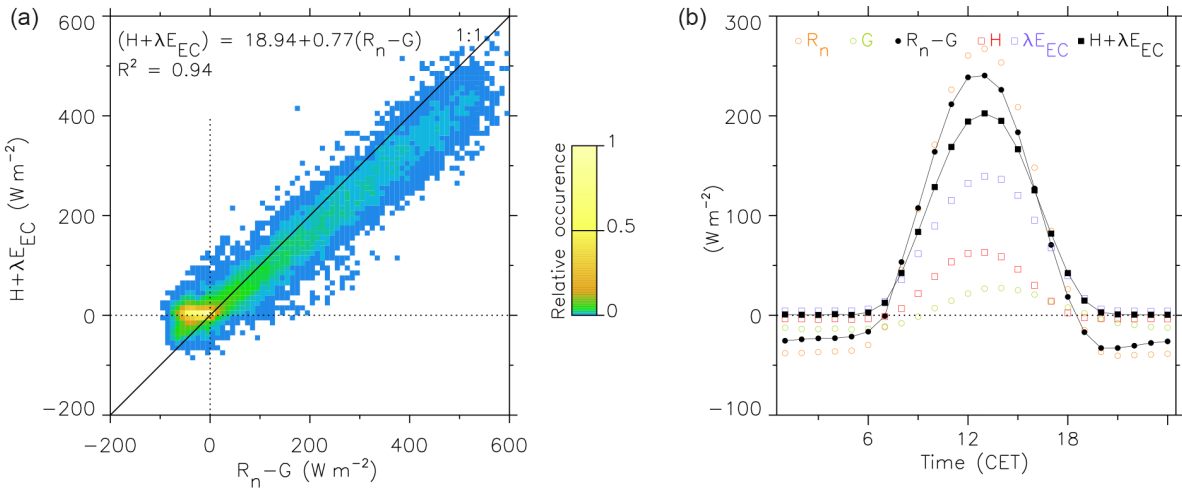

Figure 4. (a) Sum of turbulent fluxes (i.e., sum of sensible heat flux $H$ and latent heat flux $\lambda E_{\mathrm{EC}} ; H+\lambda E_{\mathrm{EC}}$ ) vs. the available energy (i.e., net radiation $R_{\mathrm{n}}$ minus surface soil heat flux $G ; R_{\mathrm{n}}-G$ ) and (b) mean daily pattern of the energy balance components. Graphs are based on measured hourly values (i.e., excluding gap-filled data, and masked for precipitation and wind directions affected by the tower) for the time period 1 June 2009-31 December 2015.

vection reveals that the magnitude of vertical advection of latent and sensible heat is small (on average at most around $-0.1 \mathrm{~W} \mathrm{~m}^{-2}$ respectively $0.05 \mathrm{~W} \mathrm{~m}^{-2}$ at noon; see Fig. S2) compared to the respective average turbulent fluxes (less than $1 \%)$. For horizontal advection, the potential effect on the energy balance closure is estimated by separating the closure analyses into three wind sectors (i.e., east, west, and south wind directions; note that sector north is completely masked due to the presence of the tower in that sector). We focus on daytime here in order to rule out biasing due to the differing distribution of nighttime fluxes among the wind sectors, which are typically small yet can have opposite directions. The results of these analyses reveal that the energy balance closure is rather independent of the wind direction (see Fig. S3). The slope and $R^{2}$ of the regression analyses are similar for all three wind sectors. This also holds for the daytime ratio of the total amount of the turbulent heat fluxes to available energy, which amounts to $86.5,86.8$, and $82.1 \%$, respectively, for the east, west, and south sectors. This robustness in the energy balance closure independent of the wind direction (in light of spatial homogeneity in the west sector and the small street and the farmhouse in the east sector; see Sect. 2.3) indicates that horizontal advection is not of great importance at the site.

The mean daily patterns of the energy balance components (Fig. 4b) show that during nighttime $H$ and $\lambda E_{\mathrm{EC}}$ often are of similar small magnitude but opposite sign, resulting in slight positive nighttime values of the sum of the turbulent fluxes and an energy balance closure gap equivalent to about the amount $R_{\mathrm{n}}-G$. The zero crossing of $R_{\mathrm{n}}$ and $H$ occurs at around 07:00 CET when $\lambda E_{\mathrm{EC}}$ starts to increase as well. $G$ is delayed by about $2 \mathrm{~h}$. All fluxes have their peak value around 13:00 CET. In the afternoon $R_{\mathrm{n}}$ and $H$ change sign again after 18:00 CET, followed by $G . \lambda E_{\mathrm{EC}}$ reaches the nighttime values at around 20:00 CET. Available energy is larger than the turbulent fluxes throughout the day. The energy balance closure gap displays a pronounced daily cycle. During nighttime the closure gap is almost constant at around $25 \mathrm{~W} \mathrm{~m}^{-2}$ and the largest closure gap is found around noon. The overall daily cycle of the energy closure gap is approximately symmetric around the noon peak, and generally increases with higher fluxes.

Figure S4 displays the daily cycles of surface and $5 \mathrm{~cm}$ soil heat fluxes, as well as of soil temperature (see Sect. 2.5). For the latter two, the average based on the three heat-flux plates and the three soil temperature sensors respectively are shown, while the range is based on the data from the three individual sensor locations (and displays the minimum and maximum values, respectively). For the surface soil heat flux, the estimate calculated from the averaged heat-flux plates and temperature sensors is displayed, along with a minimum and maximum estimate based on the individual sensor locations. The effect of the correction based on Fuchs and Tanner (1968) is clearly visible and leads to a shift of the daily cycle of the surface soil heat flux vs. the $5 \mathrm{~cm}$ soil heat flux, and to an enhancement of the daily amplitude. The range of the surface soil heat fluxes amounts to $6.7 \mathrm{~W} \mathrm{~m}^{-2}$ on the average. Especially during nighttime, this amount is substantial compared to the available energy of around $-25 \mathrm{~W} \mathrm{~m}^{-2}$. These results illustrate the spatial heterogeneity of the surface soil heat-flux footprint and underline the importance of employing a set of several soil heat-flux sensors in order to obtain spatial representativeness of the data.

\subsection{Comparison of the different evapotranspiration estimates}

In the following we compare the evapotranspiration estimates on different timescales, from yearly down to hourly timescales. The lysimeter values $E_{\mathrm{L}}$ and $E_{\mathrm{L}_{0}}$ are used as reference. The analysis is based on the period 1 June 2009 to 31 December 2015, respectively on the 6 hydrological years therein (i.e., 2009/2010 to 2014/2015). For consistency 


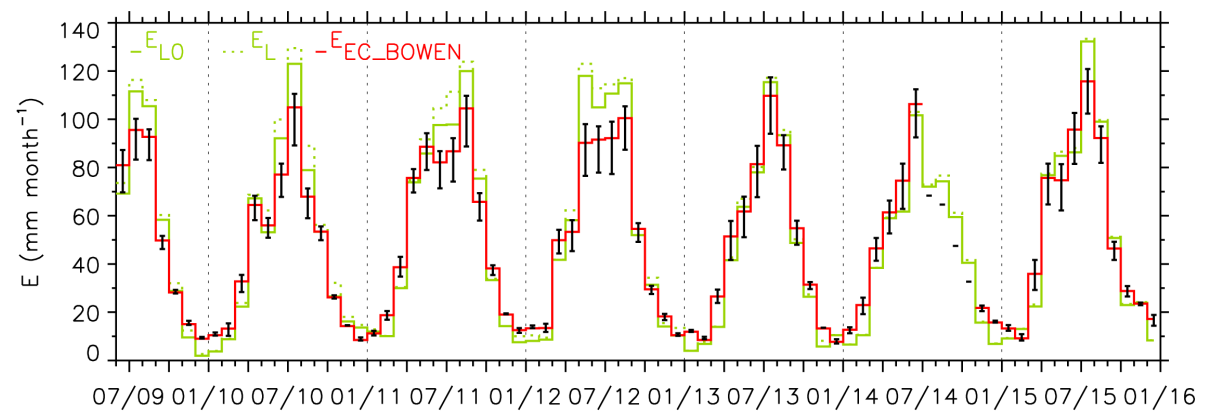

Figure 5. Monthly values of the different evapotranspiration estimates (with $E_{\mathrm{L}}$ denoting lysimeter evapotranspiration, $E_{\mathrm{L}_{0}}$ lysimeter evapotranspiration with values set to 0 during hours with precipitation, and $E_{\mathrm{EC}}$ BOWEN EC-based evapotranspiration corrected according to the Bowen ratio) for the time period June 2009 to December 2015 . The black bars indicate the range based on $E_{\mathrm{EC} H}$ and $E_{\mathrm{EC}} \mathrm{E}$ (i.e., $E_{\mathrm{EC}}$ corrected by assigning the energy balance closure gap to sensible heat-flux only and to latent heat-flux only; see Sect. 2.3). Note that from July to October 2014 an energy gap correction is not possible due to missing soil heat flux (see Sect. 2.5) and thus $E_{\mathrm{EC} \_ \text {BOWEN }}$ and $E_{\mathrm{EC} \_\mathrm{E}}$ are not available.

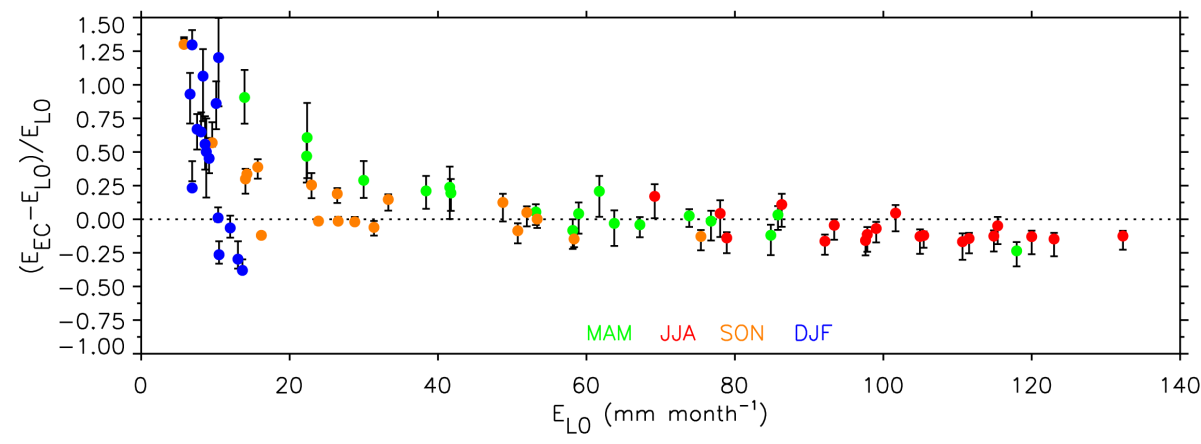

Figure 6. Monthly relative differences between lysimeter evapotranspiration $E_{\mathrm{L}_{0}}$ and EC-based evapotranspiration $E_{\mathrm{EC}}$, i.e., $\left(E_{\mathrm{EC}}-E_{\mathrm{L}_{0}}\right) / E_{\mathrm{L}_{0}}$ vs. the absolute values of $E_{\mathrm{L}_{0}}$. Different seasons are displayed in different colors. The points indicate $E_{\mathrm{EC} \_ \text {BOWEN }}$ ( $E_{\mathrm{EC}}$ corrected according to the Bowen ratio) and the black bars indicate the range based on $E_{\mathrm{EC} \_\mathrm{H}}$ and $E_{\mathrm{EC} \_\mathrm{E}}\left(E_{\mathrm{EC}}\right.$ corrected by assigning the energy balance closure gap to sensible heat-flux only and to latent heat-flux only). Note that the July to October 2014 values with missing $E_{\text {EC_BOWEN }}$ and $E_{\text {EC_E }}$ (see Sect. 2.5) are omitted.

with $E_{\mathrm{L}}$ (see Sect. 2.2), also only the upward fluxes are considered for $E_{\mathrm{EC}}$ (i.e., thus based on (neutral to) unstable conditions only). This may result in sums of $E_{\mathrm{EC} \_\mathrm{H}}$ to become higher than the sums of $E_{\mathrm{EC} \_ \text {BOWEN }}$ (depending on the distribution of the negative hourly fluxes; see Figs. 5 and 6). Note that the absolute sum of negative $E_{\mathrm{EC}}$ amounts to $2.3 \%$ of positive $E_{\mathrm{EC}}$.

Table 2 summarizes the evapotranspiration values of the different methods for the hydrological years 2009/2010 to $2014 / 2015$. The lysimeter estimates $\left(E_{\mathrm{L}}\right)$ range between 537 and $704 \mathrm{~mm} \mathrm{yr}^{-1}$. Setting evapotranspiration to 0 during precipitation events $\left(E_{\mathrm{L}_{0}}\right)$ allows for a comparison with the estimates of the eddy covariance method and reduces the values remarkably to a range of 521 to $672 \mathrm{~mm} \mathrm{yr}^{-1}$ (by up to -8 and $-5 \%$ on the average). Except for $E_{\mathrm{EC} \_\mathrm{E}}$, the eddy covariance estimates show mostly lower values than the lysimeter estimates.

The monthly evolution of $E_{\mathrm{L}_{0}}$ (and $E_{\mathrm{L}}$ for comparison) displayed in Fig. 5 displays a pronounced seasonal cycle with highest values in summer and lowest values in winter. $E_{\mathrm{L}_{0}}$ in spring is higher than in autumn. The difference of the monthly EC estimates to $E_{\mathrm{L}_{0}}$ (Figs. 5 and 6) exhibits a seasonal cycle as well, with highest absolute differences in summer when the highest fluxes occur and highest relative differences in winter. The EC estimates mostly underestimate (overestimate) $E_{\mathrm{L}_{0}}$ in summer (spring), while there is no clear tendency during autumn and winter. The $E_{\mathrm{EC} \_ \text {BOWEN }}$ estimates based on the daily force closure (see Sect. 2.3) show a consistent temporal evolution but a reduction of EC evapotranspiration compared to the one based on the hourly force closure (see Fig. S5). The underestimation of the EC estimates in summer based on the hourly force closure thus becomes slightly larger, while the rather positive EC bias in winter turns into a predominantly negative bias.

A similar picture results from the analysis of daily (not shown) and hourly evapotranspiration values. Regarding the latter, Fig. 7 displays a scatter plot of hourly values from our reference lysimeter-based evapotranspiration measure- 
Table 2. Lysimeter ( $E_{\mathrm{L}}$ and $\left.E_{\mathrm{L}_{0}}\right)$ and $\mathrm{EC}\left(E_{\mathrm{EC}}\right)$ evapotranspiration (including $E_{\mathrm{EC}}$ corrected according to the Bowen ratio ( $\left.E_{\mathrm{EC} \_ \text {BOwEN }}\right)$, and $E_{\mathrm{EC}}$ corrected by assigning the energy balance closure gap to sensible heat-flux only $\left(E_{\mathrm{EC}} \mathrm{H}_{\mathrm{H}}\right)$ and to latent heat-flux only $\left(E_{\mathrm{EC}}\right)$ ) for 6 hydrological years and the respective 6-year averages. Percentages denote the differences of $\bar{E}_{\mathrm{EC}}$ and $E_{\mathrm{L}}$ to $E_{\mathrm{L}_{0}}$. Note that for $2013 / 2014$ and 2014/2015 an energy gap correction is not possible for a 4-month period due to missing soil heat flux (see Sect. 2.5) and thus $E_{\mathrm{EC} \_ \text {BOWEN }}$ and $E_{\mathrm{EC} \_\mathrm{E}}$ are not available (denoted as NA in the table). Units in $\mathrm{mm} \mathrm{yr}^{-1}$.

\begin{tabular}{lcclll}
\hline $\begin{array}{l}\text { Hydrological } \\
\text { year }\end{array}$ & $E_{\mathrm{L}}$ & $E_{\mathrm{L}_{0}}$ & $E_{\mathrm{EC} \_\mathrm{BOWEN}}$ & $E_{\mathrm{EC} \_\mathrm{H}}$ & $E_{\mathrm{EC} \_\mathrm{E}}$ \\
\hline $2009 / 2010$ & $589(+8 \%)$ & 543 & $526(-3 \%)$ & $473(-13 \%)$ & $555(+2 \%)$ \\
$2010 / 2011$ & $704(+7 \%)$ & 659 & $614(-7 \%)$ & $545(-17 \%)$ & $652(-1 \%)$ \\
$2011 / 2012$ & $704(+5 \%)$ & 672 & $622(-7 \%)$ & $544(-19 \%)$ & $663(-1 \%)$ \\
$2012 / 2013$ & $542(+4 \%)$ & 521 & $547(+5 \%)$ & $476(-9 \%)$ & $589(+13 \%)$ \\
$2013 / 2014$ & $537(+2 \%)$ & 526 & NA & $506(-4 \%)$ & NA \\
$2014 / 2015$ & $647(+1 \%)$ & 638 & NA & $547(-14 \%)$ & NA \\
\hline Average & $621(+5 \%)$ & 593 & $577(-3 \%)$ & $515(-13 \%)$ & $615(+4 \%)$ \\
\hline
\end{tabular}
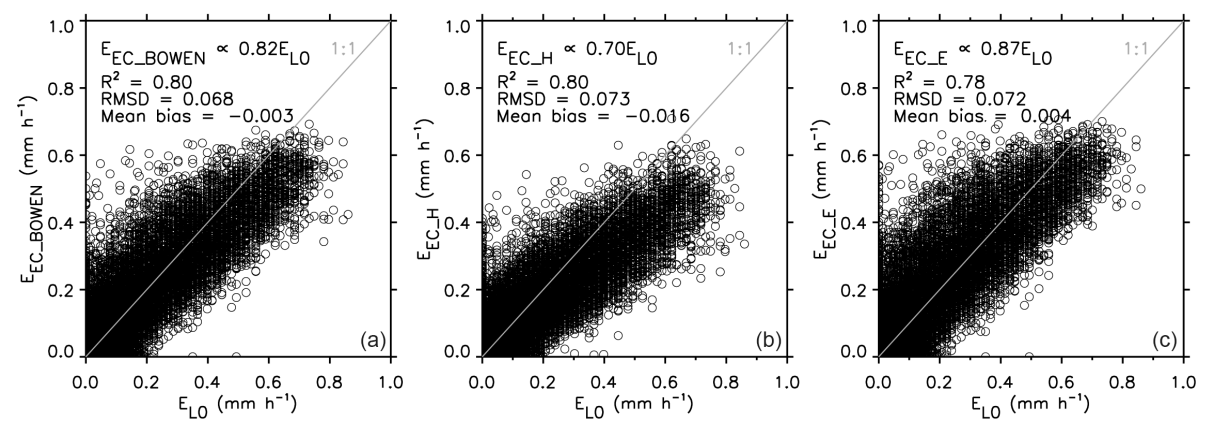

Figure 7. Comparison of hourly EC-based evapotranspiration $E_{\mathrm{EC}}$ with lysimeter evapotranspiration $E_{\mathrm{L}_{0}}$ based on measured values (i.e., excluding gap-filled data, and masked for precipitation and wind directions affected by the tower) in the time period 1 June 2009-31 December 2015 ( $n=30615$ for $E_{\mathrm{EC} \_\mathrm{H}}$ respectively $n=30002$ for $E_{\mathrm{EC} \_ \text {BOWEN }}$ and $E_{\mathrm{EC} \_\mathrm{E}}$ ). The comparison is shown separately for $E_{\mathrm{EC}}$ corrected according to (a) the Bowen ratio $\left(E_{\mathrm{EC} \_ \text {BOWEN }}\right)$, and $E_{\mathrm{EC}}$ corrected by assigning the energy balance closure gap to $(\mathbf{b})$ sensible heat-flux only $\left(E_{\mathrm{EC} \_\mathrm{H}}\right)$ and to $(\mathbf{c})$ latent heat-flux only $\left(E_{\mathrm{EC} \_\mathrm{E}}\right)$.

ment $E_{\mathrm{L}_{0}}$ and from the different EC evapotranspiration estimates for the raw measured data (excluding gaps). Overall, all EC-based estimates appear to underestimate $E_{\mathrm{L}_{0}}$ (slopes of less than 1, and negative biases except for $E_{\mathrm{EC}} \mathrm{E}$ ), in particular for high values. However, the $R^{2}$ values are similar for the different EC estimates. In addition, hourly $E_{\mathrm{EC} \_ \text {BOWEN }}$ and $E_{\mathrm{L}_{0}}$ is compared for different meteorological conditions and times of the day (see Tables S1-S3 in the Supplement). The agreement between $E_{\mathrm{EC} \_ \text {BOWEN }}$ and $E_{\mathrm{L}_{0}}$ (visible in $\mathrm{R}^{2}$ and the relative bias) is worst during nighttime when evapotranspiration is low and less variable (Tables S2 and S3). For the same reason, also low vapor pressure deficit worsens the statistics, as evapotranspiration is also lower in such conditions. Moreover, the statistics during southern wind directions are worse than for the other wind sectors (however, based on much less data). Wind speed, on the other hand, does not seem to have a strong impact on the agreement between EC and lysimeter evapotranspiration, except for the increase in relative bias for low wind speed during western wind directions (Table S1).

\section{Discussion}

\subsection{Temporal/spatial representativeness and differences between measurements}

The analysis of the hydrological year-based evapotranspiration values derived from the catchment water-balance approach $E_{\mathrm{C}}$ and from the lysimeter $E_{\mathrm{L}}$ (Fig. 3, Table 1) shows that the considered period with parallel EC and lysimeter measurements is representative and covers the climatological variability at the site well (see also Fig. 1). Despite the scale discrepancy (catchment vs. local scale), $E_{\mathrm{C}}$ and $E_{\mathrm{L}}$ overall show a similar magnitude of the fluxes. In addition, a previous comparison of the lysimeter seepage and wholecatchment runoff at monthly timescale revealed a high correlation in these measurements (Seneviratne et al., 2012). Based on this, we infer that the local-scale lysimeter measurements are representative for the whole catchment.

The difference between the EC evapotranspiration estimates and the lysimeter evapotranspiration $E_{\mathrm{L}_{0}}$ displays a seasonal dependency with the highest absolute differences in 
summer, with $E_{\text {EC_BOwEN }}$ showing about $10 \%$ lower values during this season (on the monthly timescale). On the other hand, highest relative differences occur in winter (as shown in Figs. 5 and 6). Despite these differences, it is important to note that overall good agreement between the two measurement techniques is achieved.

\subsection{Limitations/errors in the measurements}

In terms of instrumental uncertainty of EC measurements, attention was spent on the surface heating effect of the IRGA and its influence on the measured fluxes (e.g., Burba et al., 2008). Reverter et al. (2011) showed that for evaporation fluxes the impact is much smaller than for $\mathrm{CO}_{2}$. The instrument at the site is tilted downwards at an angle of $45^{\circ}$ in order to minimize the impact on the near-infrared signal by direct solar radiation, as it faces south, and thus to minimize the surface heating effect. This orientation of the IRGA also reduces the accumulation of rainwater on the optical element (see Sect. 2.3). Recently, the accuracy of the vertical wind component $w$ measured with non-orthogonal sonics and the temperature measured by sonics have been under discussion as a potential source of lack of closure. But the different studies disagree on the impact (Loescher et al., 2005; Mauder et al., 2007; Burns et al., 2012; Kochendorfer et al., 2012; Frank et al., 2013; Mauder, 2013), and further investigations are thus needed.

In addition, a drawback of the EC method is the commonly observed closure gap of the energy balance (see Sect. 2.3). The possible underlying reasons are discussed extensively in literature (e.g., Mahrt, 1998; Foken, 2008; Franssen et al., 2010; Aubinet et al., 2012; Leuning et al., 2012). Similar values and daily patterns of the energy balance closure are reported in numerous studies (e.g., Wilson et al., 2002; Franssen et al., 2010) and are also consistent with the data presented in this study. The complex determination of evapotranspiration with the EC method does not allow for a simple error analysis. The closure gap of the energy balance is taken here as an appropriate error estimate assuming an error of less than $5 \%$ in the measurement of the available energy. Thus, the bias in the turbulent fluxes is assumed to be on the order of $5-15 \%$ with a clear daily cycle and higher relative (but smaller absolute) errors during nighttime.

Our analysis also points at another contributor to an overall underestimation of turbulent fluxes by the EC method, namely the lack of reliable latent heat-flux measurements during and following precipitation events. Because of its sensitivity to precipitation, the operation of an open-path IRGA at a rainy site results in a larger fraction of erroneous data in the $E_{\mathrm{EC}}$ time series. The assumption is made that $E_{\mathrm{EC}}$ is 0 during hours with precipitation (see Sect. 2.3). But the difference between $E_{\mathrm{L}}$ and $E_{\mathrm{L}_{0}}$, which reaches up to $8 \%$ (with an underestimation for $E_{\mathrm{L}_{0}}$ ), shows that this assumption can lead to substantial underestimation of actual evapotranspiration, e.g., because it does not always rain during the entire integration period and it takes a while after a precipitation event until the optical elements are dry again. This is an interesting result for the interpretation of the EC measurements, as $E_{\mathrm{EC}}$ is often found to be closer to $E_{\mathrm{L}_{0}}$ than to $E_{\mathrm{L}}$ in this study.

Figure 8 shows the energy balance closure analysis as calculated by masking precipitation hours (left part) compared with the same analysis taking into account all hours (i.e., including precipitation hours, right part). As mentioned in Sect. 3.2, the energy closure amounts to $86.4 \%$ (for daytime and masked precipitation) for the measured turbulent fluxes (i.e., no gap correction). For the three applied forceclosing methods (see Sect. 2.3) the gap becomes closed per definition. When precipitation hours are included in the analysis, the EC-based energy balance gap becomes larger due to the additional contribution of available energy during these hours (i.e., $81.5 \%$ closure). Applying a correction for the missed latent heat flux during precipitation hours (based on the $E_{\mathrm{L}}$ vs. $E_{\mathrm{L}_{0}}$ comparison of Table 2, i.e., increasing latent heat flux by $5 \%$ on the average) results in a closure of $84.4 \%$. This shows that the amount of underestimation of latent energy during precipitation hours is substantial compared to the overall energy imbalance, contributing about $15 \%$ to the uncorrected gap (cf. $81.5 \%$ vs. $84.4 \%$ ). Applying in addition the energy gap correction of the precipitation-masked data (i.e., from Fig. 8, left part) results in closures of 97.1, 97.5 , and $97.7 \%$, respectively. Thus, the additional amount of evapotranspiration during precipitation hours as estimated by the lysimeter corresponds well with the independent measurements of available energy during these periods. It should be noted here that the amount of underestimation of evapotranspiration during precipitation periods scales with the time step used in Eqs. (1) and (2).

The site-specific error in the lysimeter evapotranspiration is discussed in Seneviratne et al. (2012). An overall measurement uncertainty of $5-10 \%$ is assumed, whereas higher errors (20\% or more, e.g., Gurtz et al., 2003) can be assumed during periods of snow cover. In the latter case, also errors in the precipitation measurement (high undercatch under snowfall, e.g., Rasmussen et al., 2012) strongly contribute to errors in $E_{\mathrm{L}}$. While these errors are large in relative terms during the affected months, they are nonetheless only affecting $E_{\mathrm{L}}$ when it is at very low values (late autumn, winter, and early spring; see Fig. 1). Hence, they should neither substantially affect the lysimeter evapotranspiration during the growing season nor when aggregated on the yearly timescale.

\section{Summary and conclusions}

We examined and compared two well-established methods to measure evapotranspiration at the site level: lysimeterbased measurements $\left(E_{\mathrm{L}}\right)$, which are common in hydrological research, and eddy covariance flux measurements $\left(E_{\mathrm{EC}}\right)$, which are widely used in micrometeorology. For the analy- 


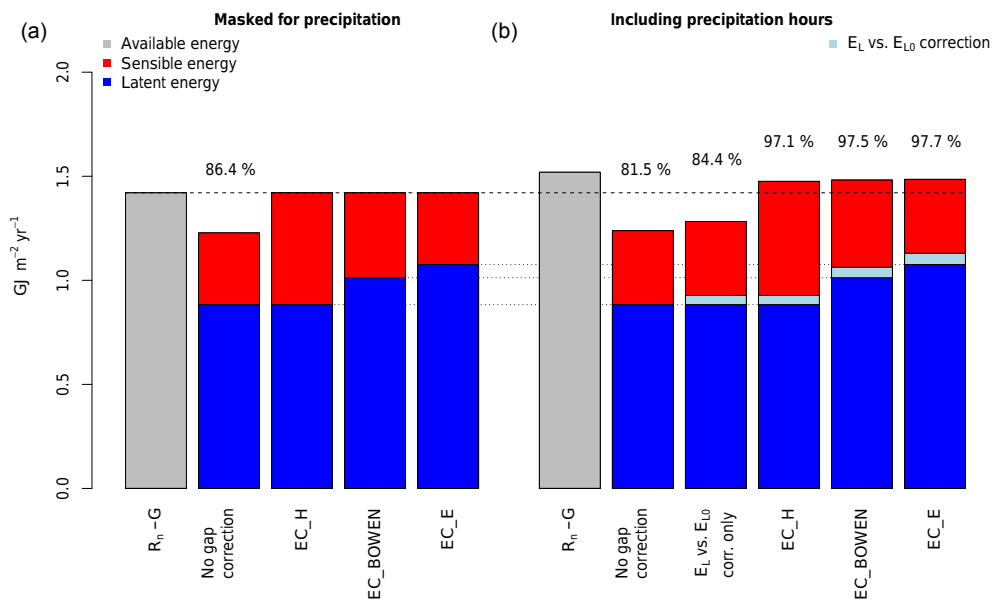

Figure 8. Yearly aggregated available energy $\left(R_{\mathrm{n}}-G\right)$ vs. sum of turbulent fluxes (for daytime, time period June 2009 to December 2015 , excluding gap-filled data), with percentages denoting the amount of closure. (a) Totals calculated from hourly data masked for precipitation. The energy closure amounts to $86.4 \%$ for the measured turbulent fluxes (i.e., no gap correction) and the gap becomes per-definition closed for the three applied corrections (i.e., correction according to the Bowen ratio EC_BOWEN, and correction by assigning the energy balance closure gap to sensible heat-flux only EC_H and to latent heat-flux only EC_E; see Sect. 2.3). (b) Totals calculated by including also precipitation hours. Here the gap is corrected by applying a correction for missed evapotranspiration during hours with precipitation (based on the lysimeter evapotranspiration estimates $E_{\mathrm{L}}$ and $E_{\mathrm{L}_{0}}$; denoted $E_{\mathrm{L}}$ vs. $E_{\mathrm{L}_{0}}$ correction) plus considering the energy gap correction based on the precipitation-masked data (see text for details).

ses, we employ parallel measurements based on these two methods carried out at a research catchment in northeastern Switzerland and covering the time period 1 June 2009 to 31 December 2015. Over this multi-year time period, the measurements were compared on yearly down to hourly timescales. Moreover, they are related to a 40-year-long lysimeter evapotranspiration time series.

Overall, the lysimeter and EC measurements agree well, in particular on the annual timescale. Also, the long-term lysimeter evapotranspiration agrees well with a catchmentwide estimate of evapotranspiration based on the catchment water balance over hydrological years (and assuming no changes in storage). This emphasizes the representativeness of the site-level lysimeter and EC measurements for the entire catchment despite their comparatively small source areas. We note, however, that the agreement is closest when the two time series are processed in the same manner, i.e., setting hourly evapotranspiration to 0 during hours with precipitation ( $E_{\mathrm{L}_{0}}$ for lysimeter record). The lysimeter measurements actually reveal the occurrence of non-negligible evapotranspiration fluxes during these periods, which leads to an underestimation of $5 \%$ on average of the total evapotranspiration fluxes with this processing. Hence, the lack of reliable EC measurements from the open-path IRGA immediately following precipitation events significantly contributes to the overall underestimation of latent heat flux from EC measurements, at least for humid sites such as Rietholzbach. Given this issue of underestimation of the EC evapotranspiration in hours with precipitation, a correction based on lysimeter estimates for these specific time periods could be possibly envis- aged in future studies for humid sites, in addition to the correction for the energy balance closure gap. We further note that the difference between the EC and $E_{\mathrm{L}_{0}}$ lysimeter evapotranspiration shows a seasonal cycle, but the same pattern on different timescales (monthly to hourly).

In conclusion, our results still highlight remaining uncertainties in the various methods and techniques available to measure and estimate evapotranspiration. Nonetheless, the good agreement of the different methodologies on yearly timescale is an important result in the context of long-term water-balance studies. In addition, our results emphasize the value of parallel lysimeter- and EC-based measurements to characterize the respective errors of these measurement systems.

\section{Data availability}

The data basis for the presented analyses is available at doi:10.5905/ethz-1007-91. The data consist of the monthly time series for the 1976-2015 time period of lysimeter evapotranspiration, lysimeter seepage, catchment runoff, air temperature, precipitation, and net radiation (see also Seneviratne et al., 2012), as well as the hourly time series for the 2009-2015 time period of lysimeter evapotranspiration and EC evapotranspiration.

The Supplement related to this article is available online at doi:10.5194/hess-21-1809-2017-supplement. 
Author contributions. Irene Lehner implemented the initial analyses for this study and co-wrote a first version of the manuscript with Sonia I. Seneviratne. Martin Hirschi and Dominik Michel revised and extended the evaluation and revised the manuscript together with Sonia I. Seneviratne. Sonia I. Seneviratne initiated and oversaw the project.

Competing interests. The authors declare that they have no conflict of interest.

Acknowledgements. We acknowledge the Federal Office for the Environment (FOEN/BAFU) for providing the runoff data, MeteoSwiss for data, as well as ETH Zurich for funding. We also thank Karl Schroff for his technical support in setting up and maintaining the measurement site.

Edited by: N. Romano

Reviewed by: S. Consoli, R. Anderson, and one anonymous referee

\section{References}

Adam, J. C. and Lettenmaier, D. P.: Adjustment of global gridded precipitation for systematic bias, J. Geophys. Res., 108, 4257, doi:10.1029/2002JD002499, 2003.

Alfieri, J. G., Kustas, W. P., Prueger, J. H., Hipps, L. E., Evett, S. R., Basara, J. B., Neale, C. M. U., French, A. N., Colaizzi, P., Agam, N., Cosh, M. H., Chavez, J. L., and Howell, T. A.: On the discrepancy between eddy covariance and lysimetry-based surface flux measurements under strongly advective conditions, Adv. Water Resour., 50, 62-78, doi:10.1016/j.advwatres.2012.07.008, 2012.

Allen, R. G., Pereira, L. S., Howell, T. A., and Jensen, M. E.: Evapotranspiration information reporting: I. Factors governing measurement accuracy, Agr. Water Manage., 98, 899-920, doi:10.1016/j.agwat.2010.12.015, 2011.

Anderson, R. G. and Wang, D.: Energy budget closure observed in paired Eddy Covariance towers with increased and continuous daily turbulence, Agr. Forest Meteorol., 184, 204-209, doi:10.1016/j.agrformet.2013.09.012, 2014.

Aubinet, M., Vesala, T., and Papale, D.: Eddy covariance: A Practical Guide to Measurement and Data Analysis, Springer, Heidelberg, New York, 438 pp., 2012.

Baldocchi, D. D., Falge, E., Gu, L., Olson, R., Hollinger, D., Running, S., Anthoni, P., Bernhofer, C., Davis, K., Fuentes, J., Goldstein, A., Katul, G., Law, B., Lee, X., Malhi, Y., Meyers, T., Munger, J. W., Oechel, W., Pilegaard, K., Schmid, H. P., Valentini, R., Verma, S., Vesala, T., Wilson, K., and Wofsy, S.: FLUXNET: a new tool to study the temporal and spatial variability of ecosystem-scale carbon dioxide, water vapor and energy flux densities, B. Am. Meteorol. Soc., 82, 2415-2435, 2001.

Burba, G. G., McDermitt, D. K., Grelle, A., Anderson, D. J., and $\mathrm{Xu}, \mathrm{L} .:$ Addressing the influence of instrument surface heat exchange on the measurements of $\mathrm{CO}_{2}$ flux from open-path gas analyzers, Global Change Biol., 14, 1854-1876, doi:10.1111/j.1365-2486.2008.01606.x, 2008.

Burns, S. P., Horst, T. W., Jacobsen, L., Blanken, P. D., and Monson, R. K.: Using sonic anemometer temperature to measure sensible heat flux in strong winds, Atmos. Meas. Tech., 5, 2095-2111, doi:10.5194/amt-5-2095-2012, 2012.

Casso-Torralba, P., Vilà-Guerau de Arellano, J., Bosveld, F., Soler, M. R., Vermeulen, A., Werner, C., and Moors, E.: Diurnal and vertical variability of the sensible heat and carbon dioxide budgets in the atmospheric surface layer, J. Geophys. Res., 113, D12119, doi:10.1029/2007JD009583, 2008.

Castellví, F. and Snyder, R. L.: A comparison between latent heat fluxes over grass using a weighing lysimeter and surface renewal analysis, J. Hydrol., 381, 213-220, doi:10.1016/j.hydrol.2009.11.043, 2010.

Chávez, J. L., Howell, T. A., and Copeland, K. S.: Evaluating eddy covariance cotton ET measurements in an advective environment with large weighing lysimeters, Irrig. Sci., 28, 35-50, doi:10.1007/s00271-009-0179-7, 2009.

Ciais, P., Reichstein, M., Viovy, N., Granier, A., Ogee, J., Allard, V., Aubinet, M., Buchmann, N., Bernhofer, C., Carrara, A., Chevallier, F., De Noblet, N., Friend, A. D., Friedlingstein, P., Grunwald, T., Heinesch, B., Keronen, P., Knohl, A., Krinner, G., Loustau, D., Manca, G., Matteucci, G., Miglietta, F., Ourcival, J. M., Papale, D., Pilegaard, K., Rambal, S., Seufert, G., Soussana, J. F., Sanz, M. J., Schulze, E. D., Vesala, T., and Valentini, R.: Europe-wide reduction in primary productivity caused by the heat and drought in 2003, Nature, 437, 529-533, doi:10.1038/nature03972, 2005.

Ding, R., Kang, S., Li, F., Zhang, Y., Tong, L., and Sun, Q.: Evaluating eddy covariance method by large-scale weighing lysimeter in a maize field of northwest China, Agr. Water Manage., 98, 87-95, doi:10.1016/j.agwat.2010.08.001, 2010.

Evett, S. R., Kustas, W. P., Gowda, P. H., Prueger, J. H., and Howell, T. A.: Overview of the Bushland Evpotranspiration and Agricultural Remote sensing Experiment 2008 (BEAREX08): A field experiment evaluating methods quantifying ET at multiple scales, Adv. Water Resour., 50, 4-19, doi:10.1016/j.advwatres.2012.03.010, 2012a.

Evett, S. R., Schwartz, R. C., Howell, T. A., Baumhard, R. L., and Copeland, K. S.: Can weighing lysimeter ET represent surrounding field ET well enough to test flux station measurements of daily and sub-daily ET?, Adv. Water Resour., 50, 79-90, doi:10.1016/j.advwatres.2012.07.023, 2012b.

Farquhar, G. D. and Sharkey, T. D.: Stomatal Conductance and Photosynthesis, Annu. Rev. Plant. Physiol., 33, 317-345, 1982.

Foken, T.: The energy balance closure problem: An overview, Ecol. Appl., 18, 1351-1367, 2008.

Foken, T., Wimmer, F., Mauder, M., Thomas, C., and Liebethal, C.: Some aspects of the energy balance closure problem, Atmos. Chem. Phys., 6, 4395-4402, doi:10.5194/acp-6-4395-2006, 2006.

Frank, J. M., Massman, W. J., and Ewers, B. E.: Underestimates of sensible heat flux due to vertical measurement errors in nonorthogonal sonic anemometers, Agr. Forest Meteorol., 171-172, 72-81, doi:10.1016/j.agrformet.2012.11.005, 2013.

Franssen, H. J. H., Stöckli, R., Lehner, I., Rotenberg, E., and Seneviratne, S. I.: Energy balance closure of eddy-covariance data: A multisite analysis for European FLUXNET stations, Agr. Forest Meteorol., 150, 1553-1567, doi:10.1016/j.agrformet.2010.08.005, 2010.

Fuchs, M. and Tanner, C. B.: Calibration and field test of soil heat flux plates, Soil Sci. Soc. Am. Proc., 32, 326-328, 1968. 
Gebler, S., Hendricks Franssen, H.-J., Pütz, T., Post, H., Schmidt, M., and Vereecken, H.: Actual evapotranspiration and precipitation measured by lysimeters: a comparison with eddy covariance and tipping bucket, Hydrol. Earth Syst. Sci., 19, 2145-2161, doi:10.5194/hess-19-2145-2015, 2015.

Goss, M. J. and Ehlers, W.: The role of lysimeters in the development of our understanding of soil water and nutrient dynamics in ecosystems, Soil Use Manage., 25, 213-223, doi:10.1111/j.1475-2743.2009.00230.x, 2009.

Gurtz, J., Verbunt, M., Zappa, M., Moesch, M., Pos, F., and Moser, U.: Long-term hydrometeorological measurements and model-based analyses in the hydrological research catchment $\mathrm{Ri}$ etholzbach, J. Hydrol. Hydromech., 51, 1-13, 2003.

Gurtz, J., Badertscher, S., Milzow, C., Moser, U., Schroff, K., Stoeckli, R., Völksch, I., and Zingg, M.: Auswertung der Messreihen der meteorologischen und hydrologischen Variablen im Forschungsgebiet Rietholzbach für den 30-jährigen Beobachtungszeitraum 1976-2005 unter besonderer Berücksichtigung des Trockensommers 2003 (Analysis of the time series of meteorological and hydrological measurements in the Rietholzbach research catchment between 1976 and 2005 with special consideration of the dry summer 2003), report, ETH Zurich, Zurich, Switzerland, 103 pp., available at: http://www.iac.ethz.ch/group/land-climate-dynamics/ research/rietholzbach/publications.html (last access: 21 February 2017), 2006.

Jaeger, E. B., Stöckli, R., and Seneviratne, S. I.: Analysis of planetary boundary layer fluxes and land-atmosphere coupling in the regional climate model CLM, J. Geophys. Res., 114, D17106, doi:10.1029/2008JD011658, 2009.

Jaun, S.: Evapotranspiration und Strahlungskomponenten im Forschungsgebiet Rietholzbach (Evapotranspiration and radiation components in the Rietholzbach research catchment), MS Thesis, Institute for Atmospheric and Climate Science, ETH Zurich, Zurich, Switzerland, 2003.

Jiménez, C., Prigent, C., Mueller, B., Seneviratne, S. I., McCabe, M. F., Wood, E. F., Rossow, W. B., Balsamo, G., Betts, A. K., Dirmeyer, P. A., Fisher, J. B., Jung, M., Kanamitsu, M., Reichle, R. H., Reichstein, M., Rodell, M., Sheffield, J., Tu, K., and Wang, K.: Global intercomparison of 12 land surface heat flux estimates. J. Geophys. Res., 116, D02102, doi:10.1029/2010JD014545, 2011.

Jung, M., Reichstein, M., Ciais, P., Seneviratne, S. I., Sheffield, J., Goulden, M. L., Bonan, G., Cescatti, A., Chen, J., de Jeu, R., Dolman, A. J., Eugster, W., Gerten, D., Gianelle, D., Gobron, N., Heinke, J., Kimball, J., Law, B. E., Montagnani, L., Mu, Q., Mueller, B., Oleson, K., Papale, D., Richardson, A. D., Roupsard, O., Running, S., Tomelleri, E., Viovy, N., Weber, U., Williams, C., Wood, E., Zaehle, S., and Zhang, K.: Recent decline in the global land evapotranspiration trend due to limited moisture supply, Nature, 467, 951-954, doi:10.1038/nature09396, 2010.

Kaimal, J. C. and Finnigan, J. J.: Atmospheric boundary layer flows, their structure and measurements, Oxford University Press, Oxford, 1994.

Katul, G., Finnigan, J. J., Poggi, D., Leuning, R., and Belcher, S. E.: The influence of hilly terrain on canopy-atmosphere carbon dioxide exchange, Bound.-Lay. Meteorol., 118, 189-216, doi:10.1007/s10546-005-6436-2, 2006.
Kljun, N., Calanca, P., Rotach, M. W., and Schmid, H. P.: A Simple Parameterisation for Flux Footprint Predictions, Bound.-Lay. Meteorol., 112, 503-523, 2004.

Kochendorfer, J., Meyers, T. P., Frank, J., Massmann, W. J., and Heuer, M. W.: How well can we measure the vertical wind speed? Implications for fluxes of energy and mass, Bound.-Lay. Meteorol., 145, 383-398, doi:10.1007/s10546-012-9738-1, 2012.

Kosugi, Y. and Katsuyama, M.: Evapotranspiration over a Japanese cypress forest. II. Comparison of the eddy covariance and water budget methods, J. Hydrol., 334, 305-311, doi:10.1016/j.jhydrol.2006.05.025, 2007.

Larcher, W.: Physiological Plant Ecology - Ecophysiology and Stress Physiology of Functional Groups, Springer-Verlag, Berlin, 513 pp., 2003.

Lee, X.: On micrometeorological observations of surface-air exchange over tall vegetation, Agr. Forest Meteorol., 91, 39-49, doi:10.1016/S0168-1923(98)00071-9, 1998.

Lee, X., Massmann, W., and Law, B.: Handbook of micrometeorology: A guide for surface flux measurement and analysis, Kluwer Academic Publishers, Dordrecht, 252 pp., 2004.

Lehner, I., Teuling, A. J., Gurtz, J., and Seneviratne, S. I.: Long-term water balance in the prealpine Rietholzbach catchment: First comparison of evapotranspiration estimates, in: Status and Perspectives of Hydrology in Small Basins, IAHS Publ., Proceedings of workshop, 30 March-2 April 2009, Goslar-Hahnenklee, Germany, 54-58, 2010.

Leuning, R., van Gorsel, E., Massman, W. J., and Isaac, P. R.: Reflections on the surface energy imbalance problem, Agr. Forest Meteorol., 156, 65-74, doi:10.1016/j.agrformet.2011.12.002, 2012.

Loescher, H. W., Ocheltree, T., Tanner, B., Swiatek, E., Dano, B., Wong, J., Zimmerman, G., Campbell, J., Stock, C., Jacobsen, L., Shiga, Y., Kollas, J., Liburdy, J., and Law, B. E.: Comparison of temperature and wind statistics in contrasting environments among different sonic anemometer-thermometer, Agr. Forest Meteorol., 133, 119-139, doi:10.1016/j.agrformet.2005.08.009, 2005.

Mahrt, L.: Flux sampling errors for aircraft and towers, J. Atmos. Ocean. Tech., 15, 416-429, 1998.

Maidment, D. R.: Handbook of Hydrology, McGraw-Hill, New York, 1424 pp., 1992.

Mauder, M.: A comment on "How well can we measure the vertical wind speed? Implications for fluxes of energy and mass" by Kochendorfer et al., Bound.-Lay. Meteorol., 147, 329-335, doi:10.1007/s10546-012-9794-6, 2013.

Mauder, M., Oncley, S. P., Vogt, R., Weidinger, T., Ribeiro, L., Bernhofer, C., Foken, T., Kohsiek, W., de Bruin, H. A. R., and Liu, H.: The energy balance experiment EBEX-2000 Part II: intercomparison of eddy-covariance sensors and post-field data processing methods, Bound.-Lay. Meteorol., 123, 29-54, 2007.

Meissner, R., Prasad, M. N. V., Du Laing, G., and Rinklebe, J.: Lysimeter application for measuring the water and solute fluxes with high precision, Curr. Sci., 99, 601-607, 2010.

Mittelbach, H., Lehner, I., and Seneviratne, S. I.: Comparison of four soil moisture sensor types under field conditions in Switzerland, J. Hydrol., 430-431, 39-49, doi:10.1016/j.jhydrol.2012.01.041, 2012.

Moore, C. J.: Frequency response corrections for eddy correlation systems, Bound.-Lay. Meteorol., 37, 17-35, 1986. 
Mueller, B., Seneviratne, S. I., Jiménez, C., Corti, T., Hirschi, M., Balsamo, G., Ciais, P., Dirmeyer, P., Fisher, J. B., Guo, Z., Jung, M., Maignan, F., McCabe, M. F., Reichle, R., Reichstein, M., Rodell, M., Sheffield, J., Teuling, A. J., Wang, K., Wood, E. F., and Zhang, Y.: Evaluation of global observations-based evapotranspiration datasets and IPCC AR4 simulations, Geophys. Res. Lett., 38, L06402, doi:10.1029/2010GL046230, 2011.

OcCC - Organe Consultatif sur les Changements Climatiques: Das Klima ändert - was nun? Der neue UN-Klimabericht (IPCC 2007) und die wichtigsten Ergebnisse aus Sicht der Schweiz, edited by: ProClim (Forum for Climate and Global Change Platform of the Swiss Academy of Sciences), Bern, 47 pp., available at: http://www.occc.ch/reports_e.html (last access: 21 February 2017), 2008.

Oki, T. and Kanae, S.: Global hydrological cycles and world water resources, Science, 313, 1068-1072, 2006.

Paw U, K. T., Baldocchi, D. D., Meyers, T. P., and Wilson, K. B.: Correction of Eddy-Covariance measurements incorporating both advective effects and density fluxes, Bound.-Lay. Meteorol., 97, 487-511, doi:10.1023/A:1002786702909, 2000.

Peter, I.: Turbulence measurements and footprint estimates at Rietholzbach, MSc Thesis, Institute for Atmospheric and Climate Science, ETH Zurich, Zurich, Switzerland, 2011.

Rana, G. and Katerji, N.: Measurement and estimation of actual evapotranspiration in the field under Mediterranean climate: A review, Eur. J. Agron., 13, 125-153, 2000.

Rasmussen, R., Baker, B., Kochendorfer, J., Meyers, T., Landolt, S., Fischer, A. P., Black, J., Theriault, J. M., Kucera, P., Gochis, D., Smith, C., Nitu, R., Hall, M., Ikeda, K., and Gutmann, E.: How well are we measuring snow? The NOAA/FAA/NCAR winter precipitation test bed, B. Am. Meteorol. Soc., 93, 811-829, doi:10.1175/BAMS-D-11-00052.1, 2012.

Reichstein, M., Bahn, M., Ciais, P., Frank, D., Mahecha, M. D., Seneviratne, S. I., Zscheischler, J., Beer, C., Buchmann, N., Frank, D. C., Papale, D., Rammig, A., Smith, P., Thonicke, K., van der Velde, M., Vicca, S., Walz, A., and Wattenbach, M.: Climate extremes and the carbon cycle, Nature, 500, 287-295, 2013.

Reverter, B. R., Carrara, A., Fernández, A., Gimeno, C., Sanz, M. J., Serrano-Ortiz, P., Sánchez-Cañete, E. P., Were, A., Domingo, F., Resco, V., Burba, G. G., and Kowalski, A. S.: Adjustment of annual NEE and ET for the open-path IRGA self-heating correction: Magnitude and approximation over a range of climate, Agr. Forest Meteorol., 151, 1856-1861, doi:10.1016/j.agrformet.2011.06.001, 2011.

Scherrer, S. C., Fischer, E. M., Posselt, R., Liniger, M. A., CrociMaspoli, M., and Knutti, R.: Emerging trends in heavy precipitation and hot temperature extremes in Switzerland, J. Geophys. Res., 121, 2626-2637, doi:10.1002/2015JD024634, 2016.

Schotanus, P., Nieuwstadt, F. T. M., and De Bruin, H. A. R.: Temperature measurement with a sonic anemometer and its application to heat and moisture fluctuations, Bound.-Lay. Meteorol., 26, 81-93, 1983.

Schume, H., Hager, H., and Jost, G.: Water and energy exchange above a mixed European Beech-Norway Spruce forest canopy: a comparison of eddy covariance against soil water depletion measurement, Theor. Appl. Climatol., 81, 87-100, doi:10.1007/s00704-004-0086-z, 2005.

Sellers, P. J., Randall, D. A., Collatz, G. J., Berry, J. A., Field, C. B., Dazlich, D. A., Zhang, C., Collelo, G. D., and Bounoua, L.:A revised land surface parameterization $(\mathrm{SiB} 2)$ for atmospheric GCMs. Part I: model formulation, J. Climate, 9, 676-705, 1996. Seneviratne, S. I., Corti, T., Davin, E. L., Hirschi, M., Jaeger, E. B., Lehner, I., Orlowsky, B., and Teuling, A. J.: Investigating soil moisture-climate interactions in a changing climate: A review, Earth Sci. Rev., 99, 125-161, doi:10.1016/j.earscirev.2010.02.004, 2010.

Seneviratne, S. I., Lehner, I., Gurtz, J., Teuling, A. J., Lang, H., Moser, U., Grebner, D., Menzel, L., Schroff, K., Vitvar, T., and Zappa, M.: Swiss prealpine Rietholzbach research catchment and lysimeter: 32 year time series and 2003 drought event, Water Resour. Res., 48, W06526, doi:10.1029/2011WR011749, 2012.

Sevruk, B.: Methods of correction for systematic error in point precipitation measurement for operational use, Oper. Hydrol. Rep. 21, WMO report no. 589, WMO, Geneva, Switzerland, 91 pp., 1982.

Teuling, A. J., Lehner, I., Kirchner, W., and Seneviratne, S. I.: Catchments as simple dynamical systems: Experience from a Swiss prealpine catchment, Water Resour. Res., 46, W10502, doi:10.1029/2009WR008777, 2010a.

Teuling, A. J., Seneviratne, S. I., Stöckli, R., Reichstein, M., Moors, E., Ciais, P., Luyssaert, S., van den Hurk, B., Ammann, C., Bernhofer, C., Dellwik, E., Gianelle, D., Gielen, B., Grünwald, T., Klumpp, K., Montagnani, L., Moureaux, C., Sottocornola, M., and Wohlfahrt, G.: Contrasting response of European forest and grassland energy exchange to heatwaves, Nat. Geosci., 3, 722727, doi:10.1038/ngeo950, 2010b.

Trenberth, K. E., Fasullo, J., and Kiehl, J.: Earth's global energy budget, B. Am. Meteorol. Soc., 90, 311-323, 2009.

Twine, T. E., Kustas, W. P., Norman, J. M., Cook, D. R., Houser, P. R., Meyers, T. P., Prueger, J. H., Starks, P. J., and Wesely, M. L.: Correcting eddy-covariance flux underestimates over a grassland, Agr. Forest Meteorol., 103, 279-300, doi:10.1016/S01681923(00)00123-4, 2000.

Wang, K. and Dickinson, R. E.: A review of global terrestrial evapotranspiration: Observation, modelling, climatology, and climatic variability, Rev. Geophys., 50, RG2005, doi:10.1029/2011RG000373, 2012.

Webb, E. K., Pearman, G. I., and Leuning, R.: Correction of flux measurements for density effects due to heat and water vapour transfer, Q. J. Roy. Meteorol. Soc., 106, 85-100, 1980.

Wetter, O., Pfister, C., Werner, J., Zorita, E., Wagner, S., Seneviratne, S., Herget, J., Grünewald, U., Luterbacher, J., Alcoforado, M.-J., Barriendos, M., Bieber, U., Brázdil, R., Burmeister, K., Camenisch, C., Contino, A., Dobrovolný, P., Glaser, R., Himmelsbach, I., Kiss, A., Kotyza, O., Labbé, T., Limanówka, D., Litzenburger, L., Nordl, Ø., Pribyl, K., Retsö, D., Riemann, D., Rohr, C., Siegfried, W., Söderberg, J., and Spring, J.-L.: The year-long unprecedented European heat and drought of 1540 - a worst case, Climatic Change, 125, 349-363, doi:10.1007/s10584-014-1184-2, 2014.

Whan, K., Zscheischler, J., Orth, R., Shongwe, M., Rahimi, M., Asare, E. O., and Seneviratne, S. I.: Impact of soil moisture on extreme maximum temperature in Europe, Weather Clim. Ext., 9, 57-67, doi:10.1016/j.wace.2015.05.001, 2015.

Wilczak, J. M., Oncley, S. P., and Stage, S. A.: Sonic Anemometer Tilt Correction Algorithms, Bound.-Lay. Meteorol., 99, 127150, doi:10.1023/A:1018966204465, 2001. 
Wilson, K., Goldstein, A., Falge, E., Aubinet, M., Baldocci, D., Berbigier, P., Bernhofer, C., Ceulemans, R., Dolman, H., Field, C., Grelle, A., Ibrom, A., Law, B. E., Kowalski, A., Meyers, T., Moncrieff, J., Monson, R., Oechel, W., Tenhunen, J., Valentini, R., and Verma, S.: Energy balance closure at FLUXNET sites, Agr. Forest Meteorol., 113, 223-243, 2002.

WMO - World Meteorological Organization: Measurement of evaporation, in: WMO Guide to Meteorological Instruments and Methods of Observation, 7th Edn., chap. 10, I.10-1-I.10-10, Geneva, Switzerland, available at: http://www.wmo.int/pages/ prog/www/IMOP/CIMO-Guide.html (last access: 21 February 2017), 2008.
Wolf, S., Eugster, W., Ammann, C., Häni, M., Zielis, S., Hiller, R., Stieger, J., Imer, D., Merbold, L., and Buchmann, N.: Contrasting response of grassland versus forest carbon and water fluxes to spring drought in Switzerland, Environ. Res. Lett., 8, 035007, doi:10.1088/1748-9326/8/3/035007, 2013. 